\title{
Silencing women in the digital age*
}

\author{
Louise Arimatsu \\ London School of Economics and Political Science, UK
}

In this paper I explore some of the ways in which developments in new digital technologies reproduce, and often amplify, the patriarchal structures, practices and culture of contemporary life and, in doing so, operate to silence women through exclusion and through violence. I consider how international human rights law - most notably the Convention on the Elimination of Discrimination Against Women (CEDAW) - can be harnessed to counter both forms of silencing in that each is rooted in gender-based discrimination. The digital gender divide and the rise in online violence against women evidences the failure on the part of States Parties to fully commit to their legal obligations pursuant to CEDAW. Ensuring equality of access to, and use of, digital technologies cannot be anything other than the preconditions to ensuring that women can benefit from, contribute to, and influence the development of digital technologies in a meaningful manner. The digital realm may be a privatised public space that warrants a reconceptualisation of the scope and content of human rights law but the fact that much of the digital infrastructure is owned and controlled by private actors does not absolve States of their human rights responsibilities.

Keywords: silence, gender, patriarchy, digital technologies, online violence against women, CEDAW

\section{INTRODUCTION}

Silence operates in multiple ways. It can represent an act of resistance or be a sign of deference, of unity, of solidarity, of remembrance, of contemplation. Silence can operate to establish and consolidate different formations of power, often hierarchical. In very many societies it functions as a manifestation of power.

In totalitarian states, silence is deployed as a technique to acquire and to reproduce power, through censorship and, as violence, in response to dissent. Thus, the ending of silence is often heralded as a marker or a sign of freedom, of liberty and of democracy. The breaking of silence constitutes a moment when what was suppressed is finally exposed, when hidden stories are released into public spaces, to be spoken about, documented and retold. But even in liberal democracies silence continues to operate in subtle and unveiled ways, including through structural silences. After all, contemporary forms of both democracy and international law are founded on the silencing of certain voices and narratives: who is entitled to speak, who they may speak to, what is heard, what is registered. Thus, to pay attention to the ways in which silence is

* This paper is based on a lecture delivered in the context of the 8th Annual Cambridge International Law Conference that took place on 20-21 March 2019 at the Faculty of Law of the University of Cambridge, UK. The author would like to thank Christine Chinkin for her invaluable comments on the draft. The author would also like to thank the Arts and Humanities Research Council, which funded the Feminist International Law of Peace \& Security project and the European Research Council, which funded the Gendered Peace project at the LSE's Centre for Women, Peace \& Security, enabling the author to find the time to write. 
employed or how it is interwoven in the formation and shaping of social relations is to gain an insight into the interests that are being protected and by whom. ${ }^{1}$

The silencing of women, through political, social, cultural or legal exclusion, marginalisation, diktat or violence has been, and remains, a common feature of patriarchy that is deeply embedded in all societies irrespective of political ideology, time or location. ${ }^{2}$ As an ideology or system of ideas and relations, patriarchy is adept at creating and utilising silence to normalise and maintain gendered inequalities that privilege particular forms of masculinity over others, and over all forms of femininity through structures, practices, culture and law. ${ }^{3}$

In this paper I explore some of the ways in which developments in new technologies reproduce, and often amplify, the patriarchal structures, practices and culture of contemporary life, and, in doing so, operate to silence women through exclusion and through violence. Although I want to think about how international law - and more specifically, international human rights law - can be harnessed to counter these trends, which if unaddressed, will result in greater inequality and injustice, I remain acutely attentive to its role or complicity in legitimising and perpetuating the very structures and processes that silence women. Over the last three decades, feminist legal scholars have generated a rich body of critical scholarship that has revealed how international law's fidelity to a binary ideology that assimilates and internalises the privileging of male - over female - coded framings, concepts and norms has reinforced gendered structures of power that remain hidden in plain sight. This work has drawn attention to the ways in which the constructed distinctions between the international/ national coupled with the public/private have operated to elide and silence, among other things, the endemic violence perpetrated against women by virtue of their gender, thereby consigning such harm beyond international law's reach through the doctrines of State sovereignty and State responsibility. ${ }^{4}$ Likewise, rather than recognising the ubiquity of gender-based violence (GBV) that manifests itself in different and constantly evolving forms, the war/peace distinction, normalised by the conditions for the applicability of international humanitarian law, has privileged some formulations of GBV whilst concealing and silencing others. ${ }^{5}$ This scholarship has also traced the ways in which international human rights law is founded on gendered assumptions

1. 'There is no binary to be made between what one says and what one does not say; we must try to determine the different ways of not saying such things, how those who can and those who cannot speak of them are distributed, which type of discourse is authorised, or which form of discretion is required in either case': Michel Foucault, The History of Sexuality: An Introduction, vol 1 (Allen Lane, London 1979) 27.

2. Gerda Lerner, The Creation of Patriarchy (OUP, Oxford 1986).

3. Patriarchy is a 'searchlight, a concept that can enable us to see what we otherwise might miss: the connective tissues between large and small, subtle and blatant forms of racialized sexism, gendered misogyny and masculinized privilege': Cynthia Enloe, The Big Push: Exposing and Challenging the Persistence of Patriarchy (1st edn, University of California Press, Oakland 2017) ix-x. See also Holly M Hapke, 'Theorizing Patriarchy: Development Paradoxes and the Geography of Gender in South Asia' (2013) 17 Gender, Technology and Development 1, 12, where patriarchy is defined as 'a set of social arrangements that privilege men, in which men as a group dominate women as a group, structurally and ideologically'.

4. Christine Chinkin, 'Violence Against Women: The International Legal Response' (1995) 3 Gender and Development 23; Hilary Charlesworth and Christine Chinkin, The Boundaries of International Law: A Feminist Analysis (Manchester UP, Manchester 2000).

5. Patricia Viseur Sellers, 'Gender Strategy is Not Luxury for International Courts' (2009) 17 Journal of Gender, Social Policy \& the Law 301. 
and consequently has been oblivious to the particular experiences and needs of women, thereby silencing them. ${ }^{6}$ The failure to register the particular harms experienced by women, often exacerbated by other axes of discrimination such as race, class and ethnicity, has resulted in further marginalisation, exclusion and silencing. On a more fundamental level, like others, I wonder whether international law's commitment to the maintenance of the existing order coupled with its universalising claims is such that any project that seeks transformation is bound to be frustrated. This paradox has long troubled feminist legal scholars who have agonised over whether, and if so how, international law can - or indeed should - be summoned to advance feminist goals. Faced with the unresolveability of this question, and all too aware of the attendant risks posed, many have nevertheless chosen to remain faithful to the discipline in the belief that it holds out the potential to advance equality, inclusivity, plurality, redistributive values, environmental sustainability and a positive peace. ${ }^{7}$ This faith has not altogether been in vain. As Dianne Otto reminds us, over the years considerable normative and institutional progress has been achieved, including advances towards more gender-inclusive interpretations of mainstream human rights instruments. ${ }^{8}$ While these developments alone cannot deliver material change on the ground - and the reality is that progress remains disappointing - I take the view that political struggles and strategies to secure further change would be far more tenuous without the legally binding obligations and the institutional mechanisms upon which to insist on enforcement and progressive change.

As with international law, the field of technology is also highly gendered terrain. Often grouped with science, engineering and maths, technology is 'firmly coded male', at least in contemporary Western society. ${ }^{9}$ The historical exclusion of women from these fields - commonly referred to as STEM - is widely acknowledged, although feminist scholars working in the field of Science and Technology Studies (STS) and feminist technoscience studies (FTS) have revealed a far more complex and ambiguous history of women's involvement in STEM, tracing the ways in which the political economy and patriarchy have operated to genderise these fields and the consequences that have followed. ${ }^{10}$ Through historical, sociological and

6. Charlotte Bunch, 'Women's Rights as Human Rights: Toward a Re-Vision of Human Rights' (1990) 12 Human Rights Quarterly 486; V Spike Peterson, 'Whose Rights? A Critique of the "Givens" in Human Rights Discourse' (1990) 15 Alternatives 303; Dianne Otto, 'Rethinking Universals: Opening Transformative Possibilities in International Human Rights Law' (1997) 18 Australian Yearbook of International Law 1; Ratna Kapur, Gender, Alterity and Human Rights: Freedom in a Fishbowl (Edward Elgar Publishing, Cheltenham 2018).

7. 'We need an international legal framework that can build solidarity rather than foster division, promote redistributive values rather than private enrichment, challenge the entrenched inequalities of the quotidian rather than normalising and exploiting them, advance positive peace rather than militarism, and ensure environmental sustainability rather than degradation': Dianne Otto (ed), Queering International Law: Possibilities, Alliances, Complicities, Risks (Routledge, New York 2018) 2.

8. Dianne Otto, 'Gender Issues and International Human Rights: An Overview' (2012) Melbourne Legal Studies Research Paper No $606<$ https://ssrn.com/abstract=2154770> accessed 11 July 2019.

9. Francesca Bray, 'Gender and Technology' (2007) 36 Annual Review of Anthropology 37,38 .

10. Studies show how women were excluded from technology as a result of the male domination of skilled trades which emerged during the Industrial Revolution. See Ruth Milkman, Gender at Work: The Dynamics of Job Segregation During World War II (University of 
cultural analyses, this scholarship, which critically explores the relationship between gender, science and technology, ${ }_{11}^{11}$ is not only reinstalling women's presence into the histories of the techno-sciences ${ }^{12}$ but is seeking to reconstitute our understanding of these fields, founded on the insight that each has been made masculine. ${ }^{13}$ Thus, such approaches have disrupted the hitherto common distinction between 'basic' and 'applied' science; ${ }^{14}$ questioned prevailing interpretations of what constitutes technology $;^{15}$ unsettled dominant assumptions about the neutrality of science and technology; ${ }^{16}$ and uncovered the ways in which the technosciences have produced gendered power differentials and layers of marginalisation, exclusion and silences. By drawing attention to the binary divisions that are 'foundational to modern science, including division of

Illinois Press, Urbana 1987); Cynthia Cockburn, Brothers: Male Dominance and Technological Change (Pluto Press, London 1991). Other scholarship has revealed how the introduction of female labour is usually accompanied by a downgrading of the skill content of the work and consequent fall in the pay for the job. As Phillips and Taylor observe, 'far from being an objective economic fact, skill is often an ideological category imposed on certain types of work by virtue of the sex and power of the workers who perform it': Anne Phillips and Barbara Taylor, 'Sex and Skill: Notes Towards a Feminist Economics' (1980) 6 Feminist Review 79, 79. 11. By the late 1980s attention in feminist technology studies was tending to shift away from the focus on 'women and technology' to gender: see Cynthia Cockburn and Susan Ormrod, Gender and Technology in the Making (1st edn, Sage Publications, London 1994) 3.

12. Jennifer S Light, 'When Computers Were Women' (1999) 40 Technology and Culture 455; Janet Abbate, 'Women and Gender in the History of Computing' (2003) 25 IEEE Annals of the History of Computing 4; Janet Abbate, Recoding Gender: Women's Changing Participation in Computing (MIT Press, Cambridge MA 2012); Hilde G Corneliussen, 'Making the Invisible Become Visible: Recognizing Women's Relationship with Technology' (2014) 6 International Journal of Gender, Science and Technology 209.

13. The earlier conceptions of 'technology' included other practices such as needlework, spinning and mining, but it was in the 1930s that technology was redefined as applied science (rather than art) and appropriated by engineering, an exclusively middle-class white male preserve. This re-moulding of what constitutes 'technology' laid the foundation for the second claim that femininity was no longer compatible with technological pursuits. See, in particular, Ruth Oldenziel, Making Technology Masculine: Men, Women and Modern Machines in America 1870-1945 (Amsterdam University Press, Amsterdam 1999). More recent scholarship seeks to understand women's underrepresentation in technology and how this might be reversed. For example, Hicks reveals how women's underrepresentation in technology is often a social, rather than an economic or educational, problem. See Marie Hicks, 'Meritocracy and Feminization in Conflict: Computerization in the British Government' in Thomas J Misa (ed), Gender Codes: Why Women are Leaving Computing (1st edn, John Wiley, Hoboken 2010). Lagesen explores the different strategies that are being trialled to explain and to reverse the underrepresentation of women in digital technologies; see Vivian Anette Lagesen, 'The Strength of Numbers: Strategies to Include Women into Computer Science' (2007) 37 Social Studies of Science 67. 14. The use of the term 'technoscience' by critical scholars is intended to challenge the distinction between 'basic' and 'applied' science. According to Asberg and Lykke, for researchers "there is no such thing as a pure and politically innocent "basic" science that can be transformed into technological applications to be "applied" in "good" or "bad" ways at a comfortable distance from the "clean" hands of the researcher engaged in the former': Cecilia Åsberg and Nina Lykke, 'Feminist Technoscience Studies' (2010) 17 European Journal of Women's Studies 299, 299.

15. Historical and cultural constructions of gender have determined what is defined as technology: see n 12 .

16. Ellen Balka and Richard Smith (eds), Women, Work and Computerization: Charting a Course to the Future (Kluwer, Boston 2000); Abbate, Recoding Gender: Women's Changing Participation in Computing (n 12); Misa (n 13). 
subject and object, human and nonhuman, nature and culture', ${ }^{17}$ feminist STS scholars working in cybernetics ${ }^{18}$ artificial intelligence ${ }^{19}$ and physics ${ }^{20}$ have not only questioned the politics of such ordering but have sought to disrupt conventional constructions of knowledge founded on difference by excavating the symmetries and fluidity between human and nonhuman, discursive and material, subjectivity and embodiment enriched by intersectional analyses. ${ }^{21}$ The need to critically engage with the sociocultural shaping of science and technology is integral to much of this scholarship given the co-productive/dialectical relation between gender and these fields of study and practice. ${ }^{22}$ In the words of Judy Wajcman, 'gender relations can be thought of as materialised in technology, and gendered identities and discourses as produced simultaneously with technologies' ${ }^{23}$ For feminist technoscience scholars, the need to increase women's participation in the STEM fields is not only a matter of equality and necessary to the eradication of all other oppressive power disparities of the contemporary world but, to the extent that we live in a society that is constituted by science and technology - and gender power relations shape and are shaped by technosciences - women's full participation is pivotal to ensuring greater diversity and an enriched development of the technosciences that allow for alternative futures. This rationale holds true for many feminist international law scholars.

The advent of digital and biomedical technologies was regarded by FTS scholars as a potential game-changer. ${ }^{24}$ In particular, it was maintained, digital technologies ${ }^{25}$ would create new spaces and tools for political activism and for enhancing diversity

17. Lucy Suchman, 'Agencies in Technology Design: Feminist Reconfigurations' (2004) 2 $<$ https://www.lancaster.ac.uk/fass/resources/sociology-online-papers/papers/suchman-agenciestechnodesign.pdf> accessed 11 July 2019.

18. See eg Donna Haraway, 'A Manifesto for Cyborgs: Science, Technology and Socialist Feminism in the 1980s' (1987) 2(4) Australian Feminist Studies 1.

19. Lucy Suchman, Plans and Situated Actions: The Problem of Human-Machine Communication (CUP, Cambridge 1987).

20. Karen Barad, 'Getting Real: Technoscientific Practices and the Materialisation of Reality' (1998) 10 Differences 87.

21. The material feminist and feminist post-humanist scholarship was very much inspired by the insights of the feminist technosciences. See eg the rich body of scholarship by Rosi Braidotti: 'Rosi Braidotti' <https://rosibraidotti.com/> accessed 11 July 2019.

22. See Judy Wajcman, Feminism Confronts Technology (Polity Press, Cambridge 1991); Cockburn and Ormrod (n 11). For example, in their study on the microwave oven, Cockburn and Ormrod trace how technology, including the artefact itself, is shaped by gender relations and how gender identity is likewise shaped by technology. This means that neither technology nor gender can be fully understood without appreciating the complex and intimate relationship between both.

23. Judy Wajcman, 'From Women and Technology to Gendered Technoscience' (2007) 10 Information, Communication and Society 287, 293.

24. In addition to 'information and communication technologies' (ICTs), genetic engineering and reproductive technologies would likewise challenge traditional notions of gender identity and this would in turn transform new technologies.

25. The term 'digital technologies', or indeed ICTs, raise complex definitional questions, which I have deliberately chosen not to address in this paper. Instead, I use the terms interchangeably and treat them as expansive and fluid. For a generous definition, see Marcelle, who suggests that ICTs 'comprise a complex and heterogeneous set of goods, applications and services used to produce, distribute, process and transform information. They include the outputs of industries as diverse as telecommunications, television and radio broadcasting, computer hardware and software, computer services and electronic media (e.g. the internet, 
through dialogue, and offer the possibility to transform how power would be renegotiated and redistributed. Moreover, the anonymity of cyberspace introduced the potential to destabilise gender difference, thereby transforming gender relations and further empowering women. ${ }^{26}$ But where are we today? To what extent has this technology disrupted the embodied sex difference between men and women? Or, indeed, advanced gender equality? In thinking about these questions and more, I borrow from the work of Cynthia Enloe, who is best known for her cutting-edge scholarship on militarism and international politics, to ask the question: where are the women? ${ }^{27}$ Doing so helps reveal the specificity of different women's lives: 'women' are not a homogenous group and nor are all women are silenced, at least not in the same way. Moreover, to ask 'where are the women?' also requires that we recognise the gendered features and gendered impacts of digital technologies, as FTS scholars have been doing. How are digital technologies implicated in gender inequalities? How does this technology bear on gender relations? How are technological outcomes shaped by gender? And finally, as my interest is located at the intersection of technology and law, what is the role of international law in regulating this technology? Can it do so without entrenching gendered hierarchical relations? How might a feminist international law assist in maximising the potential of ICTs to empower women and secure a social order free of discrimination and committed to peaceful coexistence?

The remainder of this paper is in three sections. In Section 2, I explore how patriarchal structures, practices and culture continue to exclude women from accessing and using ICTs and the implications thereof. I then turn to examine how the international human rights architecture is being invoked to contest the gendered trajectory of digital technologies and to challenge patriarchy's silencing of women. Notwithstanding the emancipatory appeal of digital technologies, I remain troubled by the misgiving that, all too often, the inclusion of women is on patriarchy's terms. In Section 3, I develop this argument through the lens of online gender-based violence against women. I close with some reflections in Section 4, in which I suggest that women are being doubly silenced by the patriarchal culture that permeates the digital space and by the failure on the part of States to meet their core human rights obligations. ${ }^{28}$ Digital technologies may have resulted in the dispersion of power, but in the privatised public space of the digital realm, where power resides with non-State actors, international human rights law has less traction. This leads me to ask whether a wholesale reimagining of its scope and content is merited.

electronic commerce and computer games)': Gillian Marcelle, 'Transforming Information and Communication Technology for Gender Equality', Gender in Development Monograph Series No 9 (UNDP, New York 2000) 5.

26. See eg Sadie Plant, Zeros + Ones: Digital Women and the New Technoculture (Fourth Estate, London 1998). Digital technologies, Plant suggests, would blur the line between human and nonhuman and disrupt the embodied sex difference between male and female.

27. Although they do not expressly refer to Enloe's work, as demonstrated, feminist technoscience scholars have been asking the same questions.

28. See eg Dhanaraj Thakur, 'How Do ICTs Mediate Gender-Based Violence in Jamaica?' (2018) 26 Gender and Development 267, 276-277; Christine Chinkin and Madeleine Rees, 'How New Technologies Are Violating Women's Rights in Saudi Arabia' (21 March 2019) $<$ https://blogs.lse.ac.uk/wps/2019/03/21/how-new-technologies-are-violating-womens-rights-insaudi-arabia/> accessed 11 July 2019. 


\section{DIGITAL TECHNOLOGY, POWER AND EXCLUSION}

The global growth in internet uptake has occurred at a rate well beyond all expectations. The announcement in 2018 by the UN's specialised agency for ICTs - the International Telecommunications Union (ITU) - that half the global population, or $51.2 \%$, now has access to and are using the internet was much celebrated. For those operating within the international institutional structures, this was regarded as an important milestone since the prevailing view had long been that ICTs would enhance political, economic and social empowerment. Digital technologies would create new spaces of political engagement, promote greater transparency and accountability, and facilitate government and public-sector efficiency; ${ }^{29}$ such technologies would also enhance social empowerment through knowledge sharing, and enable greater access to education, healthcare and other social services; and finally ICTs would promote economic empowerment through the creation of new industries (including, for example, new devices, artificial intelligence), new relationships (through globalisation), and new employment opportunities. Thus, the dominant belief was that the ICT revolution would not only provide solutions to economic and social problems such as inadequate resources, unemployment and centralisation, but that digital technologies would assist in alleviating poverty, advance development, ${ }^{30}$ and, significantly, resolve the problem of marginalisation including in respect of women. Although the potential of ICTs to empower women had been recognised by the global women's movement by at least the mid $1990 \mathrm{~s},{ }^{31}$ the primary focus of States during this

29. One potentially transformative benefit of digital technologies which I do not address in this paper but is worth noting concerns registration and documentation. For many women in the Global South the lack of documentation in relation to identity/status (birth, marriage and death certificates) often prevents them from being able to claim rights and to access basic provisions. The denial of their 'right to have rights' is a gendered form of discrimination that is further exacerbated by poverty and forced displacement.

30. Best exemplified by the fact that ICTs were made an integral component of Goal 8 of the UN's Millennium Development Goals: see 'MDG 8: Develop a Global Partnership for Development' (MDG Monitor, 15 November 2016) <www.mdgmonitor.org/mdg-8-develop-a-global-partner ship-for-development/> accessed 19 July 2019. In 2000, the G8 approved a policy document, the Okinawa Charter on the Global Information Society (see Ministry of Foreign Affairs of Japan, 'Okinawa Charter on Global Information Society' <www.mofa.go.jp/policy/economy/sum mit/2000/charter.html> accessed 29 July 2019), which was followed up in 2001 with an ICT action plan, Digital Opportunities for All: Meeting the Challenge ICT (see 'Digital Opportunities for All: Meeting the Challenge' (G8 Genoa, 11 May 2001) <www.g7.utoronto.ca/summit/2001genoa/dot force1.html $>$ accessed 29 July 2019), emphasising the potential for poverty reduction, increased social inclusion and creation of better life for all. The potential and significance of ICTs to development was also being embraced in other international fora. See eg United Nations Development Programme, 'Human Development Report 2001: Making New Technologies Work for Human Development' (OUP, New York 2001); and World Bank, 'Partnerships for Development' in The World Bank Annual Report 2001: Year in Review, vol 1 (World Bank, Washington DC 2001) <http://documents.worldbank.org/curated/en/624991468764410016/Year-in-review> accessed 29 July 2019, 101-105. See also the 2003 and 2005 'UN World Summit on the Information Society': ITU, 'World Summit on the Information Society' <www.itu.int/net/wsis/> accessed 19 July 2019; and Peter Ekdahl and Lena Trojer, 'Digital Divide: Catch up for What?' (2002) 6 Gender, Technology and Development 1, 2.

31. That ICTs were not gender-neutral was recognised as early as 1995 at the Fourth World Conference on Women. Although digital technologies were still in their infancy, the Beijing Declaration acknowledged media as one of the 12 'areas of concern'. Chapter J, on 'Women and 
early period was on expanding access to ICTs among and between States rather than as a means to further the political and social empowerment of women within States as was being urged by feminist activists and scholars. ${ }^{32}$

By the late 1990s the original euphoria was somewhat dampened by the realisation that the digital revolution was deepening the socio-economic divide between countries, with the least developed being left further behind. ${ }^{33}$ Rather than closing the poverty gap, poverty was functioning to exclude access to ICTs, which was further entrenching material and non-material poverty. Today, 3.5 billion people still have no ICT access, the vast majority of whom are located in the poorest countries in Africa and Asia. ${ }^{34}$ Within countries, ICTs were reproducing the same pattern. Not only were 'new technologies travel[ling] on old social relations' ${ }^{35}$ but pre-existing disparities were being accentuated by digital technologies, further excluding already marginalised communities, including women. By 2003, the digital gender divide was high on the agenda of the international community.

Although the availability of sex - and gender - disaggregated global ICT penetration data is limited, ${ }^{36}$ the ITU's 2017 statistics indicate that the proportion of men using the internet remains higher than the proportion of women doing so in two-thirds

the Media', specified that '[w]omen should be empowered by enhancing their skills, knowledge and access to the information technology. This will strengthen their ability to combat negative portrayals of women internationally and to challenge instances of abuse of power of an increasingly important industry ... . Women therefore need to be involved in decision-making regarding the development of the new technologies in order to participate fully in their growth and impact'; the strategic objective was to 'increase the participation and access of women to expression and decision-making in and through the media and new technologies of communication': UN Women, 'Platform for Action' (The United Nations Fourth World Conference on Women, September 2005) <www.un. org/womenwatch/daw/beijing/platform/media.htm> accessed 11 July 2019.

32. United Nations Division for the Advancement of Women, 'Gender Equality and Empowerment of Women Through ICT' (2005) Women 2000 and Beyond <www.un.org/ womenwatch/daw/public/w2000-09.05-ict-e.pdf> accessed 11 July 2019.

33. See ILO, World Employment Report 2001: Life at Work in the Information Economy (ILO, Geneva 2001).

34. As Lee shows, it was the neoliberal economic policies adopted during this period that proved hugely damaging, widening existing inequalities rather than narrowing them. In particular, from the 1980s onwards, State-owned telecommunications sectors in industrialised countries were denationalised to compete in international fora. Developing countries were also encouraged to follow suit by the international financial institutions which simultaneously decreased lending to the sector to promote liberalisation and foreign investment. The consequence of these policies was to reproduce the same relationships of dependency between North and South found in other sectors and to widen the in-country gender gap. Paradoxically, it is the Global South that is held responsible for failing to address in-country inequalities as though the broader neoliberal policies championed by many in the North and international arenas are irrelevant. See Micky Lee, 'A Feminist Political Economic Critique of the Human Development Approach to New Information and Communication Technologies' (2011) 73 The International Communication Gazette 524.

35. Vandana Shiva, 'Lecture at Lulea University of Technology' (Lulea University of Technology, 5 March 1998), quoted in Pirjo Elovaara and Christina Mörtberg, 'Design of Digital Democracies: Performances of Citizenship, Gender and IT' (2007) 10 Information, Community and Society 404, $415<\mathrm{https} / / \mathrm{www}$.tandfonline.com/doi/pdf/10.1080/ 13691180701410091? needAccess=true > accessed 3 September 2019.

36. The ITU's technostrategic language is reminiscent of the gendered cultural environment of the defence intellectual as described by Carol Cohn: see Carol Cohn, 'Sex and Death in the Rational World of Defense Intellectuals' (1987) 12 Signs 687. 
of countries worldwide: $50.9 \%$ versus $44.9 \%$. In other words, there are approximately 200 million fewer women than men online. But perhaps more troubling is the fact that the global gender digital divide has grown from $11 \%$ in 2013 to just under $12 \%$ in 2017 , primarily due to the widening gap in Africa which has increased from $20 \%$ to $25 \% .{ }^{37}$ This trend, coupled with the fact that in the least developed countries only one out of seven women is using the internet compared with one out of five men, makes for disturbing reading. Globally, the disparity in access and use between urban and rural communities and among different age groups shows that the most disproportionately disadvantaged group is poorer, older women in rural communities. ${ }^{38}$ This reality is one that feminist activists and researchers have been forewarning against for at least two decades. ${ }^{39}$ Notwithstanding the emancipatory potential of ICTs, women have long been alert to the risk that, in the absence of proactive interventions by States, women, and in particular those who face multiple intersecting discriminations, would be left behind.

The growing body of empirical research being generated by scholars, particularly in the field of development studies, is providing a far more contextual understanding of the impediments to access and use that are confronted by differently situated women most notably, but not exclusively, in the Global South. ${ }^{40}$ While these research outputs

37. Since 2013 the gender gap has narrowed in most regions. See ITU, 'Bridging the Gender Divide' <www.itu.int/web/pp-18/en/article/bridging-the-gender-divide> accessed 29 July 2019; ITU, 'ITU Gender Dashboard' <www.itu.int/en/action/gender-equality/data/Pages/ie.aspx?/en/ action/gender-equality/data/Pages/default.aspx $>$ accessed 29 July 2019; and the statistics available at ITU, 'Statistics' <www.itu.int/en/ITU-D/Statistics/Pages/stat/default.aspx> accessed 29 July 2019.

38. In rural areas, the gender gap is higher in high-income countries: $9.4 \%$, compared to $7.5 \%$ in low- and middle-income countries. This trend is somewhat reversed in urban areas, where the gap is slightly higher - at $6.6 \%$ - in low- and middle-income countries, than in high-income countries $(6.3 \%)$. While this data on urban-rural internet use is only available for 16 out of the 69 countries covered in the ITU's dataset, these findings on the urban gap are consistent with other research. For example, the Web Foundation's Women's Rights Online research surveyed urban poor communities in ten low- and middle-income countries and found that women were nearly $50 \%$ less likely to access the internet than men in the same communities: see World Wide Web Foundation, 'Women's Rights Online: Translating Access into Empowerment' (20 October 2015) <https://webfoundation. org/research/womens-rights-online-2015/> accessed 11 July 2019. The digital gender gap increases as age increases and is more significant in low- and middle-income countries. Among 15-24 year olds, the gender gap is $2.9 \%$ in low- and middle-income countries. However, there is a negative gap for this age group in high-income countries, where internet use among women is slightly higher - by $0.5 \%$ - than men. The gender gap in internet use grows among the 25-74 age group across all countries, but is higher again for low- and middle-income countries $(7.7 \%)$ compared to high-income countries $(3.5 \%)$. When we look at the age group 75 and above, the gender gap becomes significantly larger, with an average gap of $45.8 \%$ across all countries. Again, these findings are supported by the Women's Rights Online research, which also shows the gender gap increasing with age in urban poor communities. 39. Writing in 2002, Huyer and Carr urged: 'it is imperative that attention be paid now if women (especially women living in poverty) are not to be excluded from the benefits of this technological revolution as they were with the agricultural and industrial revolutions in the past'. See Sophia Huyer and Marilyn Carr, 'Information and Communication Technologies: A Priority for Women' (2002) 6 Gender, Technology and Development 85, 87.

40. See eg studies cited by Ahmed Tareq Rashid, 'Digital Inclusion and Social Inequality: Gender Differences in ICT Access and Use in Five Developing Countries' (2016) 20 Gender, Technology and Development 306, 309-310. See also ITU, 'The Gender Digital 
are providing granularity, for many working in the field the findings come as no surprise. For example, in too many societies girls and women continue to be prevented from acquiring basic literacy and language skills, let alone computer skills, by patriarchal structures, institutions and cultures. ${ }^{41}$ Studies show that common barriers include the diversion of family savings to providing dowries for girls rather than investing in their education; the prevalence of early marriage for girls; the failure to cater for the specific needs of girls and women in educational establishments; and gender stereotyping. ${ }^{42}$ Even when women have managed to acquire basic IT skills, the fact that on average they spend 2.6 times more time than men on unpaid care and domestic work means that they have less time to acquire new IT skills and knowledge. The knock-on effect of this reality is that they are often confined to lower-skilled jobs and, with less income, accessibility to and use of ICTs becomes that much more unaffordable. The lack of dependable ICT infrastructure coupled with restricted access to public access sites, including internet cafes - which are often inhospitable sites for women and girls - further discriminate against women's ability to access ICTs. ${ }^{43}$ Patriarchal socio-cultural norms often mean that in traditional communities the male members of the household retain control over women's and girls' access to the technology. ${ }^{44}$ In conflict zones these barriers are magnified many times over where internet access is even more limited, power cuts are common and ownership of a digital device, let alone its use, can draw unwelcome attention from both within and outside the family. Although the advent of the mobile phone - the now dominant means of accessing internet in developing countries - was welcomed by many as a technological development that could mitigate some of the aforementioned barriers confronting women, the numbers convey a disappointing story. According to 2018 OECD figures, women worldwide are on average $26 \%$ less likely to have a smartphone than men. In real terms, this translates to 327 million fewer women having smartphone access to the

Inclusion Map: Research Methodology' (2016) <www.itu.int/en/action/gender-equality/ PublishingImages/Pages/EQUALS/The\%20Gender\%20Digital\%20Inclusion\%20Map\%20-\% 20Research\%20Methodology.pdf> accessed 19 July 2019, in which the gender digital divide is described as 'a gender-driven imbalance in access to [ICTs], general ICT literacy and presence in [science, technology, engineering and mathematics] studies'.

41. See UNESCO, Global Education Monitoring Report Gender Review: Meeting Our Commitments to Gender Equality in Education (UNESCO, Paris 2018) <https://unesdoc. unesco.org/ark:/48223/pf0000261593> accessed 11 July 2019.

42. Elizabeth Kiondo, 'Millennium Development Goals: Challenges and Opportunities for Using ICTs to Promote Gender Equality in Africa' (2007) 71 Empowering Women for Gender Equity 16.

43. Empirical studies show that 'for many women, ICTs remain inaccessible due to affordability issues associated with poverty, lack of basic technological skills, low levels of literacy and numeracy, geographic isolation, and poor technical infrastructure that is often associated with it, as well as the cultural expectations, norms, and mores that influence the ability of women to own and/or access ICTs in public places': Tait Brimacombe and Andrew Skuse, 'Gender, ICTs, and Indicators: Measuring Inequality and Change' (2013) 17 Gender, Technology and Development 131, 135. Similar findings are also documented by Steeves and Kwami on a pilot project in Ghana which had 'fail[ed] to address digital inequities rooted in fundamental social and structural problems': H Leslie Steeves and Janet Kwami, 'Interrogating Gender Divides in Technology for Education and Development: The Case of the One Laptop per Child Project in Ghana' (2017) 52 Studies in Comparative International Development 174, 188.

44. Steeves and Kwami (n 43). 
internet. ${ }^{45}$ Moreover, studies show that women are less likely to utilise mobile data, social media apps or SMS services. ${ }^{46}$ These trends indicate that while some technological innovations might facilitate greater access and use, until 'the discrimination faced by women in society, be it based on location, economic status, age, gender, racial or ethnic origin, social and cultural norms, education or other factors' are fully addressed by States, the digital gender gap is likely to subsist if not grow. ${ }^{47}$

In a world that is becoming increasingly digitised, the implications of exclusion from access to and use of ICTs raise serious concerns, direct and indirect, immediate and long-term. Exclusion is already leaving many women less equipped than men to exercise their human rights and to benefit from the technology on an equal footing with men. Thus, rather than being an empowering technology, ICTs are functioning to deepen inequalities in respect of a broad spectrum of rights including, for example, by depriving women of relevant and timely information around health and reproductive rights to enable them to exercise the right to health. ${ }^{48}$ Likewise, digital exclusion has compounded pre-existing inequalities in respect of the right to education and training, the right to take part in cultural life, access to justice, and to participate in public affairs, among other rights. For as long as women are excluded from access and use, they are less likely to be in a position to benefit from ICTs on a basis of equality, let alone contribute to or influence the trajectory and content of this technology. 49 The knock-on effect of this is that through ICTs, gendered power differentials will become further entrenched and digital technologies will simply reproduce a patriarchal order, which 'will only serve to further disenfranchise women and at best, relegate women to the role of consumers of the technology'. ${ }^{50}$ The insidious and banal ways in which digital technologies are legitimating and reproducing a gendered global order, not

45. For the latest Global System for Mobile Communications Mobile Gender Gap Report, see Oliver Rowntree, 'Connected Women: The Mobile Gender Gap Report 2019' (GSMA 2019) $<$ www.gsma.com/mobilefordevelopment/resources/mobile-gender-gap-report-2019/> accessed 11 July 2019.

46. Alina Sorgner and Christiane Krieger-Boden, 'Empowering Women in the Digital Age' (G20 Insights, 5 July 2017) <www.g20-insights.org/policy_briefs/empowering-women-digitalage/> accessed 11 July 2019; OECD, 'More Needs to be Done to Bridge the Digital Gender Divide' (30 October 2018) <www.oecd.org/newsroom/more-needs-to-be-done-to-bridge-thedigital-gender-divide.htm> accessed 11 July 2019.

47. UNHRC, 'Promotion, Protection and Enjoyment of Human Rights on the Internet: Ways to Bridge the Gender Digital Divide from a Human Rights Perspective' (5 May 2017) UN Doc A/ $\mathrm{HRC} / 35 / 9$, para 17.

48. UNHRC, 'Report of the Special Rapporteur on the Promotion and Protection of the Right to Freedom of Opinion and Expression, Mr Frank La Rue' (20 April 2010) UN Doc A/HRC/14/ 23 , para 44.

49. The 'gender digital divide' is defined by OHCHR as 'the measurable gap between women and men in their access to, use of and ability to influence, contribute to and benefit from ICTs': UNHRC (n 47) para 3. In other words, the gender digital divide problem is far more complex and nuanced and is not simply one of penetration which often assumes that access and use translates to benefits. See ITU, 'The ICT Development Index (IDI): Conceptual Framework and Methodology' <www.itu.int/en/ITU-D/Statistics/Pages/publications/mis2017/methodology. aspx $>$ accessed 11 July 2019. As FTS scholars have demonstrated, the equal access discourse tends to render invisible multiple other variables such as class, race, religion, etc.

50. Nicholas O Alozie and Patience Akpan-Obong, 'The Digital Gender Divide: Confronting Obstacles to Women's Development in Africa' (2017) 35 Development Policy Review 137, 142. 
only through digital consumption ${ }^{51}$ but through the integration of gendered norms into the very design of digital technologies, including through algorithms, ${ }^{52}$ makes the need to ensure that women are in a position to shape the direction and content of this technology a pressing one. ${ }^{53}$

Thus, while parity of access and use is critical, these objectives cannot be anything other than the preconditions to ensuring that women can benefit from, contribute to and influence the development of digital technologies in a meaningful manner. ${ }^{54}$ What steps are States taking, if any, to address the divide?

\subsection{CEDAW}

The predisposition on the part of States to develop ICT strategies framed by security and economic priorities rather than through an egalitarian gender-sensitive lens has been remarked on by feminist scholars who have scrutinised national strategies. For example, following an in-depth study of India's ICT policies, Gurumurthy et al conclude that the measures adopted constitute 'strategic silences' around women and 'the erasure of gender equality as a public-political goal for policy'. ${ }^{55}$ That said, over the past several decades some States have taken steps to address the underrepresentation of women in the digital sector and more broadly across all STEM fields. ${ }^{56}$ While there may be sound policy reasons for addressing the divide, States are also under a legal obligation to do so. In fact, the existing divide, which is rooted in and sustained by sex- and gender-based discrimination, speaks to the failure on the part of States to meet their human rights obligations as set forth in a range of international

51. Victoria E Collins and Dawn L Rothe, 'The Consumption of Patriarchy: Commodification to Facilitation and Reification' (2017) 20 Contemporary Justice Review 161.

52. Byron Spice, 'Questioning the Fairness of Targeting Ads Online: CMU Probes Online Ad Ecosystem' (7 July 2015) <www.cmu.edu/news/stories/archives/2015/july/online-ads-research. html> accessed 11 July 2019; Karen Hao, 'Facebook's Ad-Serving Algorithm Discriminates by Gender and Race' (MIT Technology Review, 5 April 2019) <www.technologyreview. com/s/613274/facebook-algorithm-discriminates-ai-bias/> accessed 11 July 2019.

53. See the article by Rachel Adams and Nóra Ní Loideáin in this issue: Rachel Adams and Nóra Ní Loideáin, 'Addressing Indirect Discrimination and Gender Stereotypes in AI Virtual Personal Assistants: The Role of International Human Rights Law' (2019) 8(2) Cambridge International Law Journal 241. See also Heather Ford and Judy Wajcman, “"Anyone Can Edit”, Not Everyone Does: Wikipedia's Infrastructure and the Gender Gap' (2017) 47 Social Studies of Science 511.

54. Becky Faith, 'Maintenance Affordances and Structural Inequalities: Mobile Phone Use by Low-Income Women in the United Kingdom' (2018) 14 Information Technologies and International Development 66.

55. Anita Gurumurthy, Nandini Chami and Sanjana Thomas, 'Unpacking Digital India: A Feminist Commentary on Policy Agendas in the Digital Moment' (2016) 6 Journal of Information Policy 371, 384.

56. UNESCO estimates that less than $30 \%$ of the world's researchers in science are women; see UNESCO, 'Women in Science - Explore the Data' <www.unesco.org/new/en/naturalsciences/priority-areas/gender-and-science/improving-measurement-of-gender-equality-in-stem/ women-in-science-explore-the-data/> accessed 11 July 2019. See eg 'Women Minorities in the S\&E Workforce' in National Science Board, 'Science and Engineering Indicators 2018' (National Science Foundation 2018) <https://nsf.gov/statistics/2018/nsb20181/report/sections/ science-and-engineering-labor-force/women-and-minorities-in-the-s-e-workforce $>$ accessed 11 July 2019. 
instruments, ${ }^{57}$ most notably the 1979 Convention on the Elimination of All Forms of Discrimination Against Women $(\mathrm{CEDAW})^{58}$ which defines discrimination against women as:

any distinction, exclusion or restriction made on the basis of sex which has the effect or purpose of impairing or nullifying the recognition, enjoyment or exercise by women, irrespective of their marital status, on a basis of equality of men and women, of human rights and fundamental freedoms in the political, economic, social, cultural, civil or any other field. ${ }^{59}$

As with all human rights instruments, CEDAW encapsulates a tripartite typology of obligations requiring States to respect, protect and fulfil women's right to nondiscrimination and to the enjoyment of equality. Articles 2 and 3 of CEDAW require States Parties to condemn all forms of discrimination and to take steps - legal and policy - to ensure that women and men enjoy equal rights de jure and de facto and, where appropriate, adopt temporary special measures in accordance with Article 4 of the Convention. The obligation to ensure that women are able to access and use digital technologies on an equal basis with men may not be expressly stated in the treaty, but is captured by the expansive definition of Article 1 and reaffirmed by the broad wording of Article 3, which requires States to take all appropriate measures to ensure the full enjoyment of rights on a basis of equality 'in all fields' ${ }^{60}$ Read together, these two articles anticipate the emergence of new forms of discrimination that may not have been identified at the time of drafting. Discrimination in the digital sphere is clearly one such example. This obligation is an immediate one that must be read in conjunction with Article 24, requiring States to take all necessary measures at the national level to fully realise the rights in the Convention. ${ }^{61}$

The CEDAW Committee has emphasised, on numerous occasions, that discrimination can occur not only through the failure of States to take necessary legislative measures but through the failure to adopt national policies aimed at achieving equality. ${ }^{62}$

57. The non-discrimination provision is contained in all main international regional human rights instruments and most human rights bodies have elaborated on the obligations of States to ensure that women are not discriminated against in the use of and access to digital technologies. See eg Office of the Special Rapporteur for Freedom of Expression of the Inter-American Commission on Human Rights, 'Standards for a Free, Open and Inclusive Internet' (15 March 2017) OEA/Ser L/V/II, CIDH/RELE/INF 17/17, section D.

58. Convention on the Elimination of All Forms of Discrimination Against Women (adopted 18 December 1979, entered into force 3 September 1981) 1249 UNTS 13 (CEDAW). 189 States have ratified CEDAW, though 27 have entered reservations that are relevant to gender equality in education.

59. CEDAW (n 58) art 1.

60. Article 3 of CEDAW (n 58) states, 'States Parties shall take in all fields, in particular in the political, social, economic and cultural fields, all appropriate measures, including legislation, to ensure the full development and advancement of women, for the purpose of guaranteeing them the exercise and enjoyment of human rights and fundamental freedoms on a basis of equality with men'. See also UN Committee on the Elimination of Discrimination Against Women, 'General Recommendation No 28 on the Core Obligation of States Parties Under Article 2 of CEDAW' (16 December 2010) UN Doc CEDAW/C/GC/28, para 24.

61. See also International Covenant on Economic, Social and Cultural Rights (adopted 16 December 1966, entered into force 3 January 1976) 993 UNTS 3 (ICESCR) art 15 (1)(b), which requires States Parties to 'recognize the rights of everyone ... [t]o enjoy the benefits of scientific progress and its applications'.

62. 'General Recommendation No 28 on the Core Obligation of States Parties Under Article 2 of CEDAW' (n 60) para 10. 
It follows that in developing and implementing ICT policies and strategies, States must assess the gendered impact of the proposed measures - including those already in place - and take concrete steps to formulate and implement policies targeted towards the goal of fully eliminating all forms of discrimination against women and achieving women's substantive equality with men. ${ }^{63}$ The lack of available resources to invest in ICT infrastructure does not alleviate a State from its responsibility to ensure that women are not being disadvantaged from meaningful access and use by virtue of their sex or gender. ${ }^{64}$

Over the years, the Committee has elaborated on what practical steps States should adopt to fulfil their Article 2 obligations, stressing the importance of collecting sex-disaggregated data. ${ }^{65}$ The fact that very many States are failing to collate sexdisaggregated ICT data not only points to a lack of genuine commitment to addressing existing gender disparities, but that inaction on the part of States is nothing short of a form of silencing, since the lack or paucity of data deprives women of making the case for targeted measures. ${ }^{66}$ Insofar as targeted temporary measures are concerned, the Committee has repeatedly drawn attention to the need for States to pay special attention to those women belonging to disadvantaged and marginalised groups who confront or experience intersectional discrimination. For example, the Committee has emphasised the need for States Parties to adopt special measures to improve the access to digital technologies by rural women and girls who are disproportionately disadvantaged due to the cascading layers of obstacles they face, including poverty, geographic isolation, language barriers, lack of computer literacy and discriminatory gender stereotyping. ${ }^{67}$

As noted, State efforts to address the digital divide are, by and large, aimed at increasing the numbers of women entering the digital technology sector. Typically,

63. In elaborating on the scope and content of art 4 of CEDAW, the CEDAW Committee has stressed that States Parties are under an obligation 'to improve the de facto position of women through concrete and effective policies and programmes' and that States must 'address prevailing gender relations and the persistence of gender-based stereotypes that affect women not only through individual acts by individuals but also in law, and legal and societal structures and institutions': UN Committee on the Elimination of Discrimination Against Women, 'General Recommendation No 25 on Article 4, paragraph 1 of CEDAW (Temporary Special Measures)' (2004) UN Doc CEDAW/C/GC/25, para 7. Substantive equality, the Committee has emphasised, 'calls for an effective strategy aimed at overcoming underrepresentation of women and a redistribution of resources and power between men and women': UN Committee on the Elimination of Discrimination Against Women, 'General Recommendation No 25 on Article 4, paragraph 1 of CEDAW (Temporary Special Measures)' (2004) UN Doc

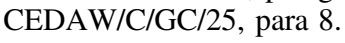

64. Whether there is a positive right to access, the internet is a separate matter from whether or not States are complying with their non-discrimination obligations. See UNHRC, 'Report of the Special Rapporteur on the Promotion and Protection of the Right to Freedom of Opinion and Expression, Mr Frank La Rue' (n 48) paras 65-66.

65. The lack of data is an indication that States Parties to CEDAW are failing to fully satisfy their obligations pursuant to Article 2 which, among other things, would require an assessment of the de jure and de facto situation of women and to be able to take concrete steps towards formulating and implementing policies to eliminate all forms of discrimination and achieve substantive equality. Given that policies must be action and results oriented, collecting relevant sexdisaggregated data is necessary.

66. Nancy J Hafkin and Sophia Huyer, 'Women and Gender in ICT Statistics and Indicators for Development' (2008) 4 Information Technologies and International Development 25.

67. UN Committee on the Elimination of Discrimination Against Women, 'General Recommendation No 34 on the Right of Rural Women' (7 March 2016) UN Doc CEDAW/ 
such programmes have included reforms in education to counter gender stereotyping, ${ }^{68}$ providing role models and mentors for girls, ${ }^{69}$ and offering incentives to women to encourage them to stay in the sector. While some of these approaches are working - and correspond with the legal obligations set forth in Articles $4,{ }^{70} 5^{71}$ and $10^{72}$ of CEDAW respectively - progress is slow. Too often, policies continue to be crafted and implemented in a piecemeal manner exemplified by the CEDAW Committee's repeated reminders to States Parties of the need to intensify efforts aimed at dispelling sexist attitudes and stereotypes ${ }^{73}$ and to strengthen efforts to encourage girls to pursue non-traditional subjects, including technology. ${ }^{74}$

C/GC/34, paras 75-76. The Committee usefully illustrates the kind of special measures that States might consider introducing, including the development of village-based or communitybased knowledge centres.

68. The need to address gender stereotyping has long been a concern of FTS scholars. As Wajcman notes, 'different childhood exposure to technology, the prevalence of different role models, different forms of schooling, and the extreme gender segregation of the job market all lead to what Cockburn describes as "the construction of men as strong, manually able and technologically endowed, and women as physically and technically incompetent": Judy Wajcman, 'Feminist Theories of Technology' (2010) 34 Cambridge Journal of Economics 143,145 . For the effects of gender stereotyping, see Eve Forster, 'As a woman in science, I need to conceal my femininity to be taken seriously' (Vox, 4 May 2017) <www.vox.com/ first-person/2017/5/4/15536932/women-stem-science-feminism> accessed 11 July 2019. See generally 'Special Issue: Girls' and Women's Participation in STEM: Past Lessons and Possible Futures' (2018) 10 International Journal of Gender, Science and Technology <http:// genderandset.open.ac.uk/index.php/genderandset/issue/view/30> accessed 11 July 2019.

69. The CEDAW Committee has emphasised the need for States to '[i]nstitute measures to increase the participation of women and girls in science, technology, engineering and mathematics programmes, at all levels of education, by providing such special incentives as scholarships and adopting temporary special measures': UN Committee on the Elimination of Discrimination Against Women, 'General Recommendation No 36 on the Right of Girls and Women to Education' (27 November 2017) UN Doc CEDAW/C/GC/36, para 63. For examples of some mentoring initiatives in North America and Europe, see Michela Cozza, 'Bridging Gender Gaps, Networking in Computer Science' (2011) 15 Gender, Technology and Science 319.

70. Article 4(1) of CEDAW (n 58) is concerned with the adoption of temporary special measures aimed at accelerating de facto equality between men and women.

71. Article 5(a) of CEDAW (n 58) specifically requires States to 'modify the social and cultural patterns of conduct of men and women, with a view to achieving the elimination of prejudices and customary and all other practices which are based on the idea of the inferiority or the superiority of either of the sexes or on stereotyped roles for men and women'.

72. Article 10 of CEDAW (n 58) lays out State obligations and establishes acceptable norms, including on equality in access to and quality of education, the reduction of female dropout rates, programmes for women and girls who have left school prematurely, and access to educational information on health and family planning. Article 16 of CEDAW expressly prohibits child marriage.

73. See eg UN Committee on the Elimination of Discrimination Against Women, 'Concluding Observations on the Seventh Periodic Report of Argentina' (25 November 2016) UN Doc CEDAW/C/ARG/CO/7; UN Committee on the Elimination of Discrimination Against Women, 'Concluding Observations on the Eighth Periodic Report of United Kingdom of Great Britain and Northern Ireland' (14 March 2019) UN Doc CEDAW/C/GBR/CO/8, paras $27-28$.

74. See UN Committee on the Elimination of Discrimination Against Women, 'Concluding Observations on the Eighth Periodic Report of United Kingdom of Great Britain and Northern Ireland' (n 73) para 42. In paragraph 63 of 'General Recommendation No 36 on the 
If States are to deliver on their obligation to achieve women's substantive equality with men, ICT strategies that seek only to increase the number of women in the sector are unlikely to achieve that aim without addressing the fact that the profession is also gender-stratified. ${ }^{75}$ As noted above, where available, gender-disaggregated data indicate that women tend to occupy lower-level ICT jobs ${ }^{76}$ or engage in part-time ICT work, thus reproducing the same patterns of gender segregation in the workplace found in other industries. ${ }^{77}$ Moreover, increased automation is projected to disproportionally impact women. ${ }^{78}$ For many women in the Global South - although not for the most marginalised - the global digital economy has created job opportunities through the outsourcing of a vast range of information-processing work from the Global North. However, often the power differentials are such that the terms of employment and working conditions remain far from ideal and the risk of exploitation is ever-present. ${ }^{79}$ As well as creating new jobs in traditional industries, digital technologies have generated new fields of media work. However, new non-routine occupations in the sector often pitched as empowering women by offering flexibility - have fudged the divide between the workplace and the home or social space and, rather than empowering women, have compounded pre-existing insecurities, added to the feminisation of poverty, ${ }^{80}$ and entrenched patriarchal assumptions around women's role in society and within the home. ${ }^{81}$

Right of Girls and Women to Education' (n 69), the Committee emphasises the need for States to address gender stereotyping (paras 25-27) pursuant to Articles 5 and 10 and, pursuant to Article 4, to adopt measures to increase the participation of women and girls in the STEM field. 75. Sectoral and occupational segregation is recognised to be one of the most detrimental aspects of gender inequality. See ILO, Women at Work Trends 2016 (ILO, Geneva 2016).

76. Or certainly work that is now categorised as 'lower' level and therefore lower paid.

77. Ann Mei Chang and Catherine Powell, 'Women in Tech as a Driver for Growth in Emerging Economies' (Council on Foreign Relations, New York 2016) <www.cfr.org/report/ women-tech-driver-growth-emerging-economies> accessed 29 July 2019. See also European Commission, She Figures 2018 (European Union, Brussels 2019).

78. Ariane Hegewisch, Chandra Childers and Heidi Hartmann, 'Women, Automation, and the Future of Work' (Institute for Women's Policy Research, 13 March 2019) <https://iwpr.org/ publications/women-automation-future-of-work/> accessed 29 July 2019.

79. For a powerful critique of the adverse impact of the digital economy, see Anita Gurumurthy, Nandini Chami and Cecilia Alemany Billorou, 'Gender Equality in the Digital Economy, Emerging Issues' (Digital Justice Project 2018) <https://itforchange.net/ digital-justice-project/issue-paper-1/> accessed 29 July 2019. See also Irem Güney-Frahm, 'A New Era for Women? Some Reflections on Blind Spots of ICT-Based Development Projects for Women's Entrepreneurship and Empowerment' (2018) 22 Gender, Technology and Development 130. Neoliberal policies have given rise to the feminisation of labour, often accompanied by deterioration of working conditions. For feminists, the most damaging aspect of neoliberal economic policies has been the paring back of the welfare/social responsibilities of the State with the concomitant transfer of social service provisions to women.

80. The lack of meaningful sex-disaggregated data compounded by the reluctance to 'go beyond the front door of domestic units' silences the complex links between women and poverty that is encapsulated by the term, 'feminization of poverty': Sarah Bradshaw, Sylvia Chant and Brian Linneker, 'Challenges and Changes in Gendered Poverty: The Feminization, DeFeminization, and Re-Feminization of Poverty in Latin America' (2019) 25 Feminist Economics 119, 138.

81. In commending the technology for providing 'women entrepreneurs with the possibility of reaching out to and communicating with customers, exploring prospective markets, attending business training courses, and networking from within the confines of their home and without the need to travel' (see United Nations Conference on Trade and Development, 'Empowering 
Article 2(e) of CEDAW requires States to take all appropriate measures to eliminate discrimination against women by any person, organisation or enterprise. As the Committee has elaborated, States have a due-diligence obligation to prevent discrimination by non-State actors. ${ }^{82}$ In practice, this means that States must have in place effective policies, legislation, regulations, and adjudication mechanisms to ensure compliance by private actors including all those operating in the ICT sector $^{83}$ and must engage all such actors and enlist their involvement in adopting measures that fulfil the goals of the Convention in the private economic sphere. ${ }^{84}$ Significantly, the extraterritorial applicability of the Convention means that the obligations of States Parties do not end at their borders. The Committee has made it unambiguously clear that States must 'take the steps necessary to prevent human rights violations perpetrated abroad by corporations over which they may exercise influence, whether through regulatory means or the use of incentives, including economic incentives' ${ }^{85}$ Likewise, as elaborated in the UN Guiding Principles on Business and Human Rights (UNGPs), business enterprises also have a responsibility to respect human rights, including those set out in CEDAW. ${ }^{86}$ The responsibility to respect requires that all businesses avoid actively participating in human rights violations, including discriminating against women, and act with due diligence to identify, assess, mitigate and remediate human rights violations. Although some companies have taken positive steps to incorporate the due-diligence operation framework throughout their business activities, many in the ICT sector have done little 'in the way of action to commit to respect human rights according to the Guiding Principles, or recognise their full range

Women Entrepreneurs through Information and Communications Technologies: A Practical Guide' (2014) UN Doc UNCTAD/DTL/STICT/2013/Rev.1, 5) there is a risk of legitimising women's exclusion from male-dominated public spheres, entrenching patriarchal norms.

82. In some instances, a private actor's acts or omission of acts may be attributed to the State under international law. See 'General Recommendation No 28 on the Core Obligation of States Parties Under Article 2 of CEDAW' (n 60) para 13; art 4, and commentary, of the ILC's Draft Articles on the Responsibility of States for Internationally Wrongful Acts in ILC, 'Report of the International Law Commission on the Work of its Fifty-Third Session' (23 April-1 June and 2 July-10 August 2001) UN Doc A/56/10, 42; UN Committee on Economic, Social and Cultural Rights, 'General Comment No 24 on State Obligations Under the ICESCR in the Context of Business Activities' (10 August 2017) UN Doc E/C.12/GC/24, para 11.

83. The ICT sector ranges from start-ups to multinational corporations and includes (but is not limited to) all aspects of infrastructure, devices, networks and applications from telecommunication companies, network operators and equipment manufacturers.

84. 'General Recommendation No 28 on the Core Obligation of States Parties Under Article 2 of CEDAW' (n 60) para 28. See also Konstantina Davaki, 'The Underlying Causes of the Digital Gender Gap and Possible Solutions for Enhanced Digital Inclusion of Women and Girls' (Study for the FEMM Committee of the European Parliament, PE 604.940, March 2018, s 2.3.

85. UN Committee on the Elimination of Discrimination Against Women, 'General Recommendation No 35 on Gender-Based Violence Against Women, Updating General Recommendation No 19' (14 July 2017) CEDAW/C/GC/35, para 24.

86. UNHRC, 'Guiding Principles on Business and Human Rights: Report of the Special Representative of the Secretary General on the Issue of Human Rights and Transnational Corporations and Other Business Enterprises, John Ruggie' (21 March 2011) UN Doc A/ HRC/17/31, para 6. See also UNHRC, 'Gender Dimensions of the Guiding Principles on Business and Human Rights: Report of the Working Group on the Issue of Human Rights and Transnational Corporations and Other Business Enterprises' (23 May 2019) UN Doc A/ HRC/41/43, para 24. The UNGPs incorporate an operational framework that requires companies to proactively assess, mitigate and remediate human rights violations. 
of impacts, negative and positive, on all human rights' ${ }^{87}$ This lack of attentiveness is particularly worrying given the wide range of rights that are implicated in the day-today operations of many within the sector. In the context of CEDAW, the responsibility to respect means that businesses, not least those in the ICT sector, should ensure that they do not actively discriminate against women in, for example, all aspects of employment (Article 11) ${ }^{88}$ or the provision of online education or training (Article 10), ${ }^{89}$ and eschew sexual stereotyping in online advertising (Article 5). ${ }^{90,91}$ However, what is clear is that neither the UNGPs - which are a soft-law instrument nor international human rights instruments, including CEDAW, create direct human rights obligations for companies under international law. The possibility of adopting a legally binding human rights treaty on business - notwithstanding the failure to do so in the past due to conceptual, legal and practical challenges ${ }^{92}$ - has nevertheless remained on the international agenda following the establishment of an open-ended intergovernmental working group in June $2014 .{ }^{93} \mathrm{I}$ will return to consider the

87. David Sullivan, 'Business and Digital Rights: Taking Stock of the UN Guiding Principles for Business and Human Rights in the ICT Sector' (Association for Progressive Communications, June 2016) <www.apc.org/en/pubs/business-and-digital-rights-taking-stockun-guidin > accessed 29 July 2019, 2. The complete indifference on the part of businesses in the sector to consider their human rights responsibilities towards employees is demonstrated by the all too standard requirement imposed by employers in the Global North on employees in the Global South to adopt Western names when engaging with customers in the Global North, thus requiring them to deny their identity, stripping them of their personhood, and silencing who they are. See Swasti Mitter, 'Globalization, ICTs, and Economic Empowerment: A Feminist Critique' (2004) 8 Gender, Technology and Development 5.

88. Article 11 of CEDAW (n 58) requires States Parties to 'take all appropriate measures to eliminate discrimination against women in the field of employment in order to ensure, on a basis of equality of men and women, the same rights'.

89. Article 10 of CEDAW (n 58) requires States Parties to 'take all appropriate measures to eliminate discrimination against women in order to ensure to them equal rights with men in the field of education'. A study of Bangladeshi NGOs providing ICT-based education revealed that the materials provided were perpetuating stereotyped concepts of the roles of men and women which, at a minimum, would infringe the spirit of Article 10(c) of CEDAW. See Sabrina Yeasmin, Mizanoor Rahman and CRK Murthy, 'Gender Analysis of Selected ICT Based Learning Materials of the Continuing Education Run by NGOS in Bangladesh' (2012) 2 Journal of Research in Gender Studies 64.

90. Article 5 of CEDAW ( $n$ 58) requires States Parties to 'take all appropriate measures: (a) To modify the social and cultural patterns of conduct of men and women, with a view to achieving the elimination of prejudices and customary and all other practices which are based on the idea of the inferiority or the superiority of either of the sexes or on stereotyped roles for men and women'.

91. UNHRC, 'Gender Dimensions of the Guiding Principles on Business and Human Rights: Report of the Working Group on the Issue of Human Rights and Transnational Corporations and Other Business Enterprises' (23 May 2019) UN Doc A/HRC/41/43.

92. See UNCHR, 'Report of the United Nations High Commissioner on Human Rights on the Responsibility of Transnational Corporations and Related Business Enterprises with Regards to Human Rights' (15 February 2005) UN Doc E/CN.4/2005/91; John Gerard Ruggie, 'Business and Human Rights: The Evolving International Agenda' (2007) 101 AJIL 819, 822.

93. For further details, see 'Open-Ended Intergovernmental Working Group on Transnational Corporations and Other Business Enterprises With Respect to Human Rights' <www.ohchr.org/ EN/HRBodies/HRC/WGTransCorp/Pages/IGWGOnTNC.aspx> accessed 11 July 2019. For a useful background note, see Ionel Zamfir, 'Towards a Binding International Treaty on Business and Human Rights' (Briefing for the European Parliament, PE 620.229, April 2018). 
implications for such a treaty for women and digital technologies in the final part of this paper.

In its most palpable form, the silencing of women through digital technologies manifests itself in exclusion from access and use in the literal sense. Exclusion, which operates on the basis of complex layers of gendered barriers that intersect with other modes of discrimination, subsists because States are failing to fulfil their human rights obligations to women and in particular to those who are already the most economically and socially disadvantaged. Social exclusion is a form of silencing, a 'non-appearance' in public discourse, which results in being written out of history and of law. The reality is that in many States, women's access to digital technologies remains a 'product of the compacts of convenience between global digital capital and patriarchal nation states'. ${ }^{94}$ As with all technologies, ICTs have the potential to empower and disempower, reproduce and entrench existing inequalities or disrupt them. Although the global digital economy has created new opportunities, all too often it has been on the terms set down by patriarchal interests in the Global North, thereby entrenching pre-existing disparities of power. Moreover, the economic benefits accrued have not always translated to social or political empowerment. As the digital economy has grown, women from all walks of life are being assimilated into the pre-existing gendered structures as users of the technology rather than as shapers and influencers. As such, their voices are silenced.

\section{VIOLENCE AND LAW IN A PRIVATISED PUBLIC SPACE}

For those with the material and non-material capacity to access and use ICTs, the technology has been empowering both as a source of information and knowledge and as a medium for creating new alliances and collective political and social action. Now populated with ever-swelling constellations of communities, the virtual public sphere has facilitated a shift in power, albeit partial and uneven, from governments to people. Many women have benefited from this dispersion of power and a strong case could be made that the technology has advanced gender equality, at least on some fronts. With the introduction of broadband, wi-fi and social media platforms, human interaction has multiplied and diversified. This technology has enabled women, in particular, to overcome the traditional barriers to public participation ${ }^{95}$ and has amplified their voices and perspectives, ${ }^{96}$ best exemplified by the \#MeToo movement. But the very same attributes of the digital space have spawned an industry of online gender-based violence against women (OGBVAW), surfacing the underbelly of patriarchy embedded within all communities and across all cultures. The backlash against \#MeToo, which has ranged from online and offline intimidation to threats and even lawsuits, typifies the often hostile digital terrain that women are having to negotiate on a daily

94. Gurumurthy et al (n 55) 393.

95. Anita Gurumurthy, 'Participatory Citizenship: Tracing the Impact of ICTs on the Social and Political Participation of Women' in Association for Progressive Communication (APC) and Humanist Institute for Cooperation with Developing Countries (Hivos), Global Information Society Watch 2013: Women's Rights, Gender and ICTs (APC and Hivos 2013) 27-28.

96. Anita Gurumurthy, 'Gender and ICTs: Overview Report' (Institute of Development Studies, University of Sussex, Brighton 2004) 38. 
basis. ${ }^{97}$ As encapsulated in the words of the UN Special Rapporteur on Violence Against Women (SRVAW), 'women and girls across the world have increasingly voiced their concern at harmful, sexist, misogynistic and violent content and behaviour online'. 98

While men and boys are also subjected to online gender-based violence, studies show that women and girls are both disproportionately targeted and suffer serious consequences as a result, including being silenced. ${ }^{99}$ States have a responsibility to prevent OGBVAW and to ensure that women are not deprived of the full enjoyment of rights due to self-censoring. Yet the record shows that while enormous efforts and resources are ploughed into addressing certain harms in the digital sphere, most notably online terrorist activities, ${ }^{100}$ comparatively little is being done to safeguard women from OGBVAW, pointing to the embedded bias that underpins the practice of States. ${ }^{101}$ The failure on the part of States to take robust measures to prevent such violence, let alone ensure women's access to justice, compounds the original harm. In reflecting further on this matter, I ask whether there is a need to be more attentive to the silencing of international law that is made possible by the constitution of the digital space as a privatised public space in contrast to the traditional conception of the public space as a site for negotiating power between the State and its citizens. My point is this: should we understand the reluctance on the part of States to commit to an international legal framework to govern the class of non-State actors who both control and dominate the space as patriarchy at work? After all, disagreements among States over the reach of human rights law, its content and its application in the digital realm have been a recipe intended or otherwise - for patriarchy to thrive in this space.

97. Michael Safi, 'India's \#MeToo Backlash: Accusers Battle Intimidation, Threats and Lawsuits', The Guardian (Delhi, 14 May 2019) <www.theguardian.com/world/2019/may/14/ indias-metoo-backlash-accusers-battle-intimidation-threats-and-lawsuits $>$ accessed 11 July 2019.

98. UNHRC, 'Report of the Special Rapporteur on Violence Against Women, Its Causes and Consequences on Online Violence Against Women and Girls from a Human Rights Perspective' (18 June 2018) UN Doc A/HRC/38/47, para 14 (emphasis added). There is much important research being done by social scientists and psychologists to understand how ICTs may be altering individual and group behaviour ('toxic disinhibition' effect) and what measures can and must be taken by States to counter this phenomenon.

99. UNHRC, 'Report of the Special Rapporteur on Violence Against Women, Its Causes and Consequences on Online Violence Against Women and Girls from a Human Rights Perspective' (n 98) para 28. In 2015 the UN Broadband Commission for Digital Development Working Group on Broadband and Gender reported that $73 \%$ of women and girls have been exposed to or experienced some form of online violence. The report ('Cyber Violence Against Women and Girls, A World-Wide Wake-up Call') was withdrawn soon after release due to 'problems' with 'footnoting'. A revised version has not as yet been released. See Heini Järvinen, 'UN Withdraws the Report on Cyber Violence Against Women' (EDRi, 21 October 2015) $<$ https://edri.org/un-withdraws-report-cyber-violence-against-women/> accessed 11 July 2019. 100. UNHRC, 'Report of the Special Rapporteur on the Promotion and Protection of the Right to Freedom of Opinion and Expression' (6 April 2018) UN Doc A/HRC/38/35, paras 15-21. 101. It was only in March 2019 that the UK Government updated its five-year strategy to tackle VAW to include online VAW. See Home Office, 'Government Sets Out Key Measures to Tackle Violence Against Women and Girls' (6 March 2019) <www.gov.uk/government/news/ government-sets-out-key-measures-to-tackle-violence-against-women-and-girls $>$ accessed 11 July 2019. The same year that the UK launched its five-year strategy, allocating $£ 80$ million (subsequently increased to $£ 100$ million), the Government launched its National Cyber Security Programme (2016-2021), budgeting £1.3 billion. 
The level, intensity and volume of the toxic abuse and misogynistic and sexist vitriol that women and girls are having to negotiate simply to remain online is difficult to quantify. ${ }^{102}$ The technology has given rise to new forms of violence including doxing, ${ }^{103}$ sextortion, ${ }^{104}$ trolling, ${ }^{105}$ mobbing, ${ }^{106}$ cyber-flashing, ${ }^{107}$ revenge porn, ${ }^{108}$ photoshopped pornography, ${ }^{109}$ tracking, ${ }^{110}$ profiling, catfishing and upskirting. ${ }^{111}$ At the same time, old forms of GBV - but perpetrated through digital platforms - such as bullying, stalking, harassment, intimidation, incitement, discriminatory and sexist hate speech, and threats of violence, rape and death are being inflicted on women on an unprecedented scale and at unprecedented speed. The technology has enabled permanent digital records, often though not exclusively of a sexualised nature, to be produced and re-produced for mass consumption worldwide, resulting in further victimisation. Technology-mediated violence against women may be appearing in new forms, but this does not mean that such acts fall outside the scope of existing international law. Article 1 of the 1993 Declaration on the Elimination of Violence Against Women (DEVAW), which reaffirms the ground-breaking definition first articulated by the CEDAW Committee, ${ }^{112}$ defines

102. Sandra Laville, 'Online Abuse: “Existing Laws Too Fragmented and Don't Serve Victims", The Guardian (4 March 2016) <www.theguardian.com/uk-news/2016/mar/04/ online-abuse-existing-laws-too-fragmented-and-dont-serve-victims-says-police-chief $>$ accessed 11 July 2019; Anita Gurumurthy and Amrita Vasudevan, 'Equality, Dignity and Privacy are Cornerstone Principles to Tackle Online VAW' (LSE Blogs, 4 December 2017) <https:// blogs.1se.ac.uk/wps/2017/12/04/equality-dignity-and-privacy-are-cornerstone-principles-totackle-online-vaw/> accessed 11 July 2019.

103. The practice of searching for and publishing private or identifying information about a particular individual on the internet, typically with malicious intent.

104. A form of blackmail in which sexual information or images are used to extort additional explicit photos, videos, sexual acts, or sex from the victim. Social media and text messages are often the source of the sexual material and the threatened means of sharing it with others.

105. The practice of creating discord on digital platforms by starting quarrels or upsetting people or provoking or inciting violence by posting inflammatory or off-topic messages, uploading images or videos, and the creation of hashtags in an online community. Many 'trolls' are anonymous and use false accounts.

106. The online bullying of an individual by a group.

107. The practice of sending obscene pictures to strangers through AirDrop or Bluetooth.

108. The distribution of sexually explicit images or video of individuals without their permission.

109. Sometimes referred to as 'deepfake pornography', the practice uses smart face-swap technology to digitally manipulate pornography to make viewers believe that the victim is present in images or film.

110. There is considerable research to show that spyware apps implanted on digital devices without knowledge of the owner have been enablers of intimate partner violence. See Rahul Chatterjee, Periwinkle Doerfler, Hadas Orgad et al, 'The Spyware Used in Intimate Partner Violence' (IEEE Symposium on Security and Privacy, San Francisco, May 2018). Digital technology and smart devices provide almost limitless ways for both private and State actors to harass and control. Google app Absher, which is owned and operated by the interior ministry of Saudi Arabia, allows men to track women's movements, including across borders. See Chinkin and Rees (n 28).

111. 'Upskirting Now a Crime After Woman's Campaign', BBC News (12 April 2019) <www. bbc.co.uk/news/uk-47902522> accessed 11 July 2019.

112. UN Committee on the Elimination of Discrimination Against Women, 'General Recommendation No 19: Violence Against Women' (1992) UN Doc A/47/38, para 6. See also 'General Recommendation No 35 on Gender-Based Violence Against Women, Updating General Recommendation No 19’ (n 85) para 14. 
violence against women as including 'any act of gender-based violence that results in, or is likely to result in, physical, sexual or psychological harm or suffering to women, including threats of such acts, coercion or arbitrary deprivation of liberty, whether occurring in public or in private life'. ${ }^{113}$ The text implicitly acknowledges that violence against women can take multiple forms, morph over time and, in the words of the CEDAW Committee, 'occurs in all spaces and spheres of human interaction' including 'online and in other digital environments'. ${ }^{114}$ OGBVAW is part of the continuum of genderbased violence against women (GBVAW) confronted by women in multiple, recurring and interrelated forms. ${ }^{115}$

As with other forms of GBV, OGBVAW is not the result of random, individual acts of misconduct. Rather, as expressly recognised in the preamble to DEVAW, violence against women is 'a manifestation of historically unequal power relations between men and women, which have led to domination over and discrimination against women by men and to the prevention of the full advancement of women' ${ }^{116}$ OGBVAW is thus the product of an ideology that seeks to normalise gender hierarchies - including through the control of women's bodies and minds - and to sustain inequalities reinforced by other systems of domination. ${ }^{117}$ Whether perpetrated online or offline, all forms of violence against women 'are used to control and attack women and to maintain and reinforce patriarchal norms, roles, and structures and an unequal power relationship'. ${ }^{118}$ As a form of violence that is directed against a woman because she is a woman, or that affects women disproportionately, OGBVAW constitutes discrimination against women and a human rights violation pursuant to CEDAW. Studies of online violence show that women are often targeted not only on the basis of their sex and gender but also on the basis of other intersecting identities. ${ }^{119}$ Women belonging to ethnic minorities, indigenous women, lesbians, bisexual and transgender women, and women with disabilities, who experience multiple and intersecting

113. Declaration on the Elimination of Violence Against Women, UNGA Res 48/104 (20 December 1993) (DEVAW). DEVAW is applicable to all States. As noted by Freeman et al, as a UNGA resolution, DEVAW may not be legally binding but, as a consensus statement of the global political body, it has significant weight: see Marsha A Freeman, Christine Chinkin and Beate Rudolf, 'Violence Against Women' in Marsha A Freeman, Christine Chinkin and Beate Rudolf (eds), The UN Convention on the Elimination of All Forms of Discrimination Against Women: A Commentary (OUP, Oxford 2012).

114. UN Committee on the Elimination of Discrimination Against Women, 'General Recommendation No 35 on Gender-Based Violence Against Women, Updating General Recommendation No 19' (n 85) para 20.

115. UNHRC, 'Report of the Special Rapporteur on Violence Against Women, its Causes and Consequences on Online Violence Against Women and Girls from a Human Rights Perspective' (n 98) para 14.

116. DEVAW (n 113) preamble.

117. Thakur (n 28); Chinkin and Rees (n 28). There is a considerable body of research which demonstrates the ways in which patriarchal oppression is inflected by other socially constructed identities. Because it does not express itself uniformly, patriarchy cannot be understood independently of other systems of oppression including but not limited to race, class, sexual orientation, gender identity, ethnicity, indigenous status and disability.

118. UNHRC, 'Report of the Special Rapporteur on Violence Against Women, its Causes and Consequences on Online Violence Against Women and Girls from a Human Rights Perspective' (n 98) para 30.

119. See in particular Amnesty International, 'Toxic Twitter - A Toxic Place for Women' (2018) <www.amnesty.org/en/latest/research/2018/03/online-violence-againstwomen-chapter-1/> accessed 11 July 2019. 
forms of discrimination offline, typically experience the same patterns of intersecting abuse online. Above all, women who have been able to amplify their voices most effectively through digital platforms, be they human rights defenders, women in or running for public office, or journalists and bloggers, have been especially targeted. ${ }^{120}$ In other words, women are targeted not only for who they are but on the basis of how much power and influence they wield in the digital domain. Moreover, in that the threats are 'generally of a misogynistic nature, often sexualized and specifically gendered', ${ }^{121}$ they aim to humiliate and objectify women to subordinate them.

The consequences of OGBVAW are tangible. ${ }^{122}$ Women who have been specifically targeted and threatened online have been subjected to physical violence offline and, in some cases, killed. ${ }^{123}$ Those who have been abused and harassed online often experience stress, anxiety, panic attacks, powerlessness and loss of confidence. ${ }^{124}$ The scale and relentlessness of the attacks, made possible by the technology, often result in serious mental harm and suffering. Sometimes victims have resorted to suicide. ${ }^{125}$ When private information, images or videos are posted online, there can be real and catastrophic social and economic consequences above and beyond the immediate psychological impact. Many women who have experienced OGBVAW have self-censored, limiting or changing how they interact online or, in some cases, have disengaged completely with social media. ${ }^{126}$ Some studies have shown that a third of women who experienced online violence have chosen to reduce their online presence, ${ }^{127}$ while in a more recent survey of women activists in Zimbabwe, Nepal and Kenya, $71 \%$ admitted to modifying their online interactions. ${ }^{128}$ Girls too have altered their online behaviour in response to online abuse. For example, a 2016 survey by a UK-based charity found that $49 \%$ of girls aged $11-16$ and $44 \%$ of young women

120. Canadian Journalists for Free Expression, 'The Pakistani Government Must Release Zeenat Shahzadi From Custody' (16 November 2017) <www.cjfe.org/the_pakistani_govern ment_must_release_zeenat_shahzadi_from_custody> accessed 11 July 2019; UNHRC, 'Situation of Women Human Rights Defenders: Report of the Special Rapporteur on the Situation of Human Rights Defenders' (10 January 2019) UN Doc A/HRC/40/60, 45-46.

121. UNHRC, 'Report of the Special Rapporteur on Violence Against Women, its Causes and Consequences on Online Violence Against Women and Girls from a Human Rights Perspective' (n 98) para 29.

122. For individual examples of the severity of the harm caused, see Emma A Jane, 'Feminist Flight and Fight Responses to Gendered Cyberhate' in Marie Segrave and Laura Vitis (eds), Gender, Technology and Violence (Routledge, London 2017) 45, 48-49.

123. 'No Country for Bold Women' (Action for a Progressive Pakistan, 16 July 2016) <https:// progpak.wordpress.com/2016/07/16/no-country-for-bold-women/> accessed 11 July 2019.

124. Amnesty International (n 119) ch 6.

125. Anita Gurumurthy and Niveditha Menon, 'Violence Against Women via Cyberspace' (2009) 44(40) Economic and Political Weekly 19.

126. Amnesty International, 'Amnesty Reveals Alarming Impact of Online Abuse Against Women' (20 November 2017) <www.amnesty.org/en/latest/news/2017/11/amnesty-revealsalarming-impact-of-online-abuse-against-women/> accessed 11 July 2019.

127. Japleen Pasricha, "Violence" Online in India: Cybercrimes Against Women and Minorities on Social Media' (Feminism in India 2016) <https://feminisminindia.com/ wp-content/uploads/2016/05/FI__cyberbullying_report_website.pdf> accessed 11 July 2019. 128. Maria Vlahakis, 'Breaking the Silence: Ending Online Violence and Abuse Against Women's Rights Activists' (Womankind Worldwide, London, November 2018) <www.womankind.org.uk/docs/default-source/default-document-library/breaking-the-silence-policy-briefing. pdf> accessed 29 July 2019. 
aged 17-21 do not feel free to express their views online. ${ }^{129}$ The study showed that $50 \%$ of girls and young women aged 11-21 think that sexism is worse online than offline, with a further $23 \%$ of respondents having had threatening things said about them on social media. Self-censoring has an adverse effect on women's ability to participate on equal terms with men in the enjoyment of their political, social, economic and cultural rights online and offline. For example, as documented by the SRVAW, some women journalists have resorted to using pseudonyms or maintain low online profiles following attacks. These defensive tactics can have a detrimental impact on their professional lives and reputations. Still others have suspended, deactivated or permanently deleted their online accounts, or left the profession entirely. ${ }^{130}$ As the SRVAW concludes, "ultimately, the online abuse against women journalists and women in the media are a direct attack on women's visibility and full participation in public life'. ${ }^{131}$

\subsection{CEDAW and countering online violence}

In recognising that women's right to a life free from GBV is indivisible from, and interdependent of, other human rights, ${ }^{132}$ the CEDAW Committee has regularly and frequently elaborated on the responsibility of States Parties to prevent such violence and has provided detailed guidance on the measures that should be taken for States to fully comply with their obligations. Such measures include having laws that criminalise all forms of GBVAW that amount to a violation of a person's physical, sexual or psychological integrity, including those perpetrated through digital technologies; to introduce, without delay, or strengthen legal sanctions commensurate with the gravity of the offence, as well as civil remedies; and to ensure that legal systems protect all victims/survivors and that they are able to access justice and are entitled to an effective remedy. ${ }^{133}$ Determining what, in practice, constitutes speech that should be criminalised, prohibited or censored may be a hard exercise, but existing human rights law already provides a framework to States within which to make such judgments. ${ }^{134}$

129. Girlguiding, 'Girls' Attitudes Survey 2016' (Girlguiding 2016) <www.girlguiding.org.uk/ globalassets/docs-and-resources/research-and-campaigns/girls-attitudes-survey-2016.pdf> accessed 11 July 2019.

130. See also OSCE Representative on Freedom of the Media, 'New Challenges to Freedom of Expression: Countering Online Abuse of Female Journalists' (OSCE, 4 February 2016) <https:// www.osce.org/fom/220411> accessed 11 July 2019.

131. UNHRC, 'Report of the Special Rapporteur on Violence Against Women, its Causes and Consequences on Online Violence Against Women and Girls from a Human Rights Perspective' (n 98) para 29. Very often the decision for many of these women to withdraw is based not only on the safety and wellbeing of themselves but also that of their immediate families, and especially children.

132. UN Committee on the Elimination of Discrimination Against Women, 'General Recommendation No 35 on Gender-Based Violence Against Women, Updating General Recommendation No 19' (n 85) para 15.

133. Ibid para 29, and UN Committee on the Elimination of Discrimination Against Women, 'General Recommendation No 33 on Women's Access to Justice' (3 August 2015) UN Doc CEDAW/C/GC/33.

134. The freedom of expression as guaranteed in Article 19 of the International Covenant on Civil and Political Rights is not an absolute right and cannot be invoked to justify language or other forms of expression designed to incite discrimination, hostility or violence as set forth in Article 20(2). For limitations to Article 19, see UNHRC, 'Report of the Special Rapporteur on the Promotion and Protection of the Right to Freedom of Opinion and Expression, Mr Frank La Rue' (n 48) paras 24-25. For a joint statement on addressing online 
Importantly, the Committee has stressed the need for States to eliminate the institutional practices and individual conduct and behaviour of public officials - in executive, legislative and judicial branches - that tolerate such violence or that provide a context for a lack of a response or for a negligent response. ${ }^{135}$ The obligation to prevent also requires States Parties to adopt and implement measures to eradicate prejudices, stereotypes and practices, as set forth in Articles 2(f) and 5(a) of CEDAW. ${ }^{136}$ In other words, States Parties must take proactive steps to develop and implement laws and policies to counter the structural root causes of GBVAW embedded across all society. In addition, the Committee has repeatedly reminded States of the need to adopt and adequately provide budgetary resources for 'diverse institutional measures' including 'the design of focused public policies, the development and implementation of monitoring mechanisms and the establishment and/or funding of competent national tribunals' pursuant to Articles 2(c), (d), and (f), and 5(a). ${ }^{137}$ The obligation to prevent OGBVAW pursuant to CEDAW is reinforced by a dense tapestry of international and regional instruments and policy commitments, which are applicable to all States. ${ }^{138}$ That States have an obligation to protect the same rights that exist offline

gender-based violence by SRVAW and the Special Rapporteur on Freedom of Expression, see OHCHR, 'UN Experts Urge States and Companies to Address Online Gender-Based Abuse but Warn Against Censorship' (8 March 2017) <www.ohchr.org/EN/NewsEvents/Pages/ DisplayNews.aspx?NewsID=21317\&LangID=E/> accessed 11 July 2019.

135. UN Committee on the Elimination of Discrimination Against Women, 'General Recommendation No 35 on Gender-Based Violence Against Women, Updating General Recommendation No 19' (n 85) para 26.

136. In light of the Concluding Observations, the CEDAW commentary observes, '[t]he Committee understands that patriarchal attitudes, cultural stereotypes (such as those of the "macho image of men"), and prejudice are structural and systemic (not private or sporadic), subordinate women, and create deep-rooted impediments to the eradication of violence against them'; see Freeman et al (n 113).

137. UN Committee on the Elimination of Discrimination Against Women, 'General Recommendation No 35 on Gender-Based Violence Against Women, Updating General Recommendation No 19' (n 85) para 26.

138. See eg the Inter-American Convention on the Prevention, Punishment and Eradication of Violence Against Women (adopted 9 June 1994, entered into force 5 March 1995) (1994) 33 ILM 1534; African Union, 'Protocol to the African Charter on Human and People's Rights on the Rights of Women in Africa' (11 July 2003); Council of Europe Convention on Preventing and Combating Violence Against Women and Domestic Violence (adopted 11 May 2011, entered into force 1 August 2014) CETS No 210; Vienna Declaration and Programme of Action (25 June 1993) UN Doc A/CONF.157/24 (Part I); Beijing Declaration and Platform for Action (15 September 1995) UN Doc A/CONF.177/20; Transforming Our World: The 2030 Agenda for Sustainable Development, UNGA Res 70/1 (25 September 2015), Goal 5; 'G20 Digital Economy Ministerial Declaration' (G20 Salta, 24 August 2018) <www.g20.utoronto.ca/2018/2018-08-24-digital.html> accessed 29 July 2019; 'Charlevoix Commitment to End Sexual and Gender-Based Violence, Abuse and Harassment in Digital Contexts' (G7 Charlevoix, 9 June 2018) <http://publications.gc.ca/site/eng/9.859335/publica tion.html> accessed 29 July 2019. Although some instruments expressly refer to online VAW, others have subsequently been interpreted to apply online. See also UNGA, 'In-Depth Study on All Forms of Violence Against Women: Report of the Secretary-General' (6 July 2006) UN Doc A/61/122/Add.1, s VI; UN Committee on the Elimination of Discrimination Against Women, 'General Recommendation No 35 on Gender-Based Violence Against Women, Updating General Recommendation No 19’ (n 85). 
in the digital sphere was affirmed by the UN Human Rights Council in $2016 .{ }^{139}$ Yet, notwithstanding these commitments, domestic efforts to implement remain dismal at best. ${ }^{140}$ Few States have taken steps to enact domestic legislation to criminalise OGBVAW. ${ }^{141}$ In sharp contrast to racist hate speech, there is a conspicuous silence around sexist hate speech, both online and offline. ${ }^{142}$ The consequence of this is that women are often left having to rely on a 'patchwork' of related offences that fail to fully capture the lived reality of the online violence they have endured. ${ }^{143}$ The failure even to register and to recognise the adverse effects of sexist and misogynist hate speech, let alone to prohibit it, is to silence the harm it causes. ${ }^{144}$ Moreover, there is growing body of research that shows that even when domestic legislation exists, there is a tendency for State authorities not to treat online abuse as a serious crime. ${ }^{145}$

139. UNHRC, 'The Promotion, Protection and Enjoyment of Human Rights on the Internet' (18 July 2016) UN Doc A/HRC/RES/32/13.

140. For example, Thakur (n 28) 267-282; Olga Jurasz and Kim Barker, 'Submission of Evidence on Online Violence Against Women to the UN Special Rapporteur on Violence Against Women, its Causes and Consequences' (2017) <https://dspace.stir.ac.uk/handle/1893/ 26282\#.XOulaohKiUk> accessed 11 July 2019. The UK government, for example, has only recently (April 2019) launched a consultation into online harm. See 'Online Harms White Paper' (8 April 2019) <www.gov.uk/government/consultations/online-harms-white-paper> accessed 11 July 2019.

141. As the SRVAW observes, 'in reality ... many States do not have a holistic legal framework on combating and preventing violence against women, including with regard to specific provisions on online and ICT-facilitated violence against women'. According to the SRVAW, the non-consensual online dissemination of intimate or sexually explicit images of an adult person is not prohibited in many States. See UNHRC, 'Report of the Special Rapporteur on Violence Against Women, its Causes and Consequences on Online Violence Against Women and Girls from a Human Rights Perspective' (n 98) paras 79, 82.

142. Commenting on online discrimination against women, among other groups, the Special Rapporteur for Freedom of Expression of the Inter-American Commission on Human Rights has reminded States Parties of their obligation to "take measures to foster equality and non-discrimination both "online" and "offline," prohibiting hate speech that incites violence, documenting instances of discrimination, and promoting tolerance through social programs, training, and education'. See Office of the Special Rapporteur for Freedom of Expression of the Inter-American Commission on Human Rights, 'Standards for a Free, Open and Inclusive Internet' (n 57) para 66.

143. In some cases, the law does not recognise a harm, however serious. See 'Revenge Porn: More Than 200 Prosecuted Under New Law', BBC News (6 September 2016) <www.bbc.co. uk/news/uk-37278264> accessed 11 July 2019.

144. 'While racist hate speech is recognised as contrary to European and international human rights standards, the same is not always true of sexist or misogynist hate speech and current policies and legislation at all levels have not been able to adequately address the issues': appendix to Council of Europe, 'Recommendation CM/Rec (2019) 1 of the Committee of Ministers to Member States on Preventing and Combating Sexism' (27 March 2019) 8. See also Christine Chinkin, 'New European Recommendation Aims to Prevent and Combat Sexism' (LSE Blogs, 14 May 2019) <https://blogs.lse.ac.uk/wps/2019/05/14/new-european-recommendationaims-to-prevent-and-combat-sexism/> accessed 11 July 2019.

145. 'Key Recommendations for Institutional Change on Gender-Based Cyber Violence: Call For Endorsements' <https://itforchange.net/e-vaw/key-recommendations/> accessed 11 July 2019. 
By blurring the public/private siloes, digital technologies have catapulted violence against women into the global public sphere making it fully visible to all, including in 'societies where the topic has long been shrouded in a cloak of silence'. ${ }^{146}$ Against this backdrop, the continued failure on the part of States to adequately respond to online misogynism and sexism is producing a culture in which women's subordination is normalised and institutionalised; in which threats and incitement to harm women are regularised; and in which physical and mental violence against women are tolerated. ${ }^{147}$

Confronted by the widespread dereliction on the part of States to tackle OGBVAW, women from across the world - individually and collectively - have resorted to selfhelp measures and, in effect, are delivering on some of the core functions of the State. Women's groups have set up helplines; shared good practice strategies through online networking and capacity-building; assisted one another in advocating for the protection of women's rights; and have been at the forefront of data gathering. ${ }^{148}$ In some cases, women have resorted to 'digilantism', utilising social media to expose offenders through 'name and shame' tactics. While this sort of feminist activism may be necessary, there are attendant risks to such strategies. After all, to take on such responsibilities is to convey an impression to the State that it is relieved from its core human rights obligations. The partial abdication by the State of some if its core functions is a trend that I see as being rooted in the spread of a neoliberal political ideology that operates on the rationale that social problems can be resolved by empowering individuals. This rationale has functioned to validate a 'light touch' approach by States, including - and most notably - in the digital sphere. It has also given rise to the now all-too-common rejoinder to those who find themselves in the digital firing line that 'developing resilience' is what is required of them. What is more, to buy into this narrative is to facilitate the downgrading of the harm, if not its total dismissal, and to

146. Loubna Hanna Skalli, 'Young Women and Social Media Against Sexual Harassment in North Africa' (2013) 19 The Journal of North African Studies 244, 245.

147. For example, commenting on the impact of online violence on women human rights defenders, the UN High Commissioner for Human Rights stated: '[i]n Vietnam, following a series of online attacks, environmental activist Le My Hanh was physically attacked last year, with the video of the attack further disseminated on social media. In India, Gauri Lankesh, a journalist who published criticism of Hindu extremism, was killed last year following widespread online calls for violence against her'. See UNHRC, 'The Impact of Online Violence on Women Human Rights Defenders and Women's Organisations: Statement by UN High Commissioner for Human Rights Zeid Ra'ad Al Hussein' (21 June 2018) <www.ohchr.org/EN/HRBodies/HRC/ Pages/NewsDetail.aspx?NewsID=23238\&LangID=E $>$ accessed 11 July 2019. Likewise, the Guidelines to Council of Europe Recommendation CM/Rec (2019) 1 on Preventing and Combating Sexism states that 'sexist behaviour such as, in particular, sexist hate speech, may escalate to or incite overtly offensive and threatening acts, including sexual abuse or violence, rape or potentially lethal action': see Council of Europe, 'Recommendation CM/Rec (2019) 1 of the Committee of Ministers to Member States on Preventing and Combating Sexism' (n 144) 4. 148. See UNHRC, 'Report of the Special Rapporteur on Violence Against Women, its Causes and Consequences on Online Violence Against Women and Girls from a Human Rights Perspective' (n 98) paras 86-88. See also Gender Equality Unit, 'Background Note on Sexist Hate Speech' (Council of Europe, 1 February 2016) s $5<\mathrm{https} / / / \mathrm{rm}$.coe.int/CoERM PublicCommonSearchServices/DisplayDCTMContent?documentId=090000168059ad42> accessed 11 July 2019. In 2006, the APC Women's Rights Programme initiated the 'Take Back the Tech!' campaign and in 2016 launched the 'Feminist Principles of the Internet'. 
shift the focus of attention away from the perpetrator. ${ }^{149}$ Thus, in the spaces of silence, neoliberalism is operating in tandem with patriarchy, locking us into sedimented ways of thinking and being, producing and re-producing hierarchical systems of power and inequalities.

But what is the responsibility of those private actors who own, economically benefit from, and control much of the infrastructure of this public space and through whose digital tools OGBVAW is made possible? The anecdotal evidence continues to show that notwithstanding their role as primary gatekeepers, the response of digital platform companies to complaints by women who have been the target of OGBVAW remains woefully inadequate. ${ }^{150}$ Although some businesses are beginning to address online violence against women, the rationale for doing so is not based on the notion of an obligation grounded in human rights law. ${ }^{151}$ Rather, it would appear that, as commercial actors operating in a space founded on the logic of private global capital, ${ }^{152}$ ensuring that the digital terrain is not a hostile space for half the world's population makes sound commercial sense. ${ }^{153}$ But this explanation alone cannot account for why it has taken so long for businesses to begin to respond to online violence against women, other than to suggest that in the spaces of silence, the neoliberal economic rationale is operating in tandem with patriarchy. I have already touched on some of the consequences that flow from the underrepresentation of women in the ICT sector which others too have described as "dominated by privilege [and] overwhelmingly male and deeply deficient in diversity'. ${ }^{154}$ As Sullivan points out, the exclusion of women as shapers and influencers within the sector necessarily means that ' $[\mathrm{t}] \mathrm{ech}$ company policies and products reflect this bias' ${ }^{155}$ This bias is deeply embedded in the design of devices to platforms, to apps and algorithms, to decisions over content flow and moderation, and to the constitution of the space itself. ${ }^{156}$ In short, patriarchal interests already determine what is privileged or expunged, who is heard or silenced in the privatised public sphere of the digital world. If this is indeed the case, should feminist activists be championing for a legally binding human rights treaty to hold

149. Anita Gurumurthy and Amrita Vasudevan, 'Hidden Figures: A Look at TechnologyMediated Violence Against Women in India' (June 2018) <https://itforchange.net/index.php/ hidden-figures-a-look-at-technology-mediated-violence-against-women-india> accessed 11 July 2019.

150. The Fawcett Society, 'Twitter is "Failing Women" Experiencing Online Threats and Harassment' (22 August 2017) <https://www.fawcettsociety.org.uk/News/twitter-failingwomen-experiencing-online-threats-harassment> accessed 11 July 2019.

151. Sullivan (n 87) 2.

152. Digital technologies are deeply implicated in the valorisation of private benefit.

153. The 'outsourcing' of public policy to private intermediaries is a topic that has garnered a significant body of literature. See eg Arne Hintz, 'Restricting Digital Sites of Dissent: Commercial Social Media and Free Expression' (2016) 13 Critical Discourse Studies 325; Sarah Jeong, The Internet of Garbage (Vox Media, Washington DC 2018).

154. Sullivan (n 87) 6.

155. Ibid. FTS scholars have documented how technological innovation is shaped by sex of the workforce and gender relations within the workplace.

156. 'Social media platforms and the private companies that run them are potent because they have become vital components of the digital public sphere. How they design their platforms, how they allow content to flow, and how they agree to exchange information with competing platforms have direct implications for both communication rights and innovation': L DeNardis and A M Hackl, 'Internet Governance by Social Media Platforms' (2015) 39 Telecommunications Policy 761, 769. 
businesses to account in international law, notwithstanding the reluctance on the part of States to do so? ${ }^{157}$ Is a wholesale reimagining of the scope and content of international human rights law that goes beyond the proposed 'Zero Draft' treaty released in June 2018 merited? ${ }^{158}$

\section{FEMINIST INTERNATIONAL LAW: ON BEING HEARD}

The Zero Draft treaty adopts a traditional approach to international law-making in that it creates international obligations only for States. Accordingly, businesses will be held legally accountable for human rights violations pursuant to 'legislative and other measures' that States Parties will be required to enact under domestic law to meet their treaty obligations. To ensure legal compliance, States are also expected to introduce legislation requiring businesses to undertake effective due diligence - to identify, prevent, mitigate and account for how they address the adverse human rights impact in the course of their business activities. Importantly, the draft requires States to ensure that victims of violations have access to a remedy and, to that extent, responds to one of the core demands of civil society. The draft text has prompted debate and criticism from various quarters ${ }^{159}$ and there are signs that the European Union has decided to drop out of the process altogether. ${ }^{160}$

In its current form, the treaty makes fleeting reference to women, requiring that businesses carry out 'meaningful consultations with groups whose human rights are potentially affected' as part of their due-diligence obligation and, in so doing, give 'special attention to those facing heightened risks of violations of human rights within the context of business activities, such as women, children, persons with disabilities, indigenous peoples, migrants, refugees and internal displaced persons'. ${ }^{161}$ The reference feels suspiciously like a last-minute add-on and the opportunity to fully integrate

157. Human rights experts remain divided on intermediary liability. For differing views, see eg Carly Nyst, 'Towards Internet Intermediary Responsibility' (GenderIT, 26 November 2013) $<$ www.genderit.org/feminist-talk/towards-internet-intermediary-responsibility $>$ accessed 11 July 2019; and Anita Gurumurthy, 'How the Online Space for Women is in a Crisis and What Needs to be Done About It' (March 2019) <https://itforchange.net/how-online-spacefor-women-a-crisis-and-what-needs-to-be-done-about-it> accessed 11 July 2019.

158. UNHRC Open-Ended Intergovernmental Working Group on Transnational Corporations and Other Business Enterprises with Respect to Human Rights, 'Legally Binding Instrument to Regulate, in International Human Rights Law, the Activities of Transnational Corporations and Other Business Enterprises' (16 July 2018) <www.ohchr.org/Documents/HRBodies/ HRCouncil/WGTransCorp/Session3/DraftLBI.pdf> accessed 11 July 2019 (Zero Draft).

159. See eg Business and Human Rights Resource Centre, 'Statements, Initiatives and Commentaries' <https://www.business-humanrights.org/en/binding-treaty/statements-initiativescommentaries> accessed 29 July 2019; Carlos Lopez, 'Towards an International Convention on Business and Human Rights (Part I)' (Opinio Juris, 23 July 18) <http://opiniojuris.org/2018/07/ 23/towards-an-international-convention-on-business-and-human-rights-part-i/> accessed 11 July 2019; Antonella Angelini, 'When It Comes to Human Rights, Zero is Better than Nothing' (Fair Observer, 1 October 2018) <www.fairobserver.com/politics/un-human-rights-businesscorporate-responsibility-treaty-news-01900/> accessed 11 July 2019.

160. Friends of the Earth Europe, 'Leaked Document Reveals EU's Decision to Withdraw from Proposed UN Binding Treaty Negotiations' (15 March 2019) <www.business-humanrights.org/ en/leaked-document-reveals-eus-decision-to-withdraw-from-proposed-un-binding-treaty-negotiations $>$ accessed 11 July 2019.

161. Zero Draft (n 158) art 9(2); see also arts 15(4) and (5). 
a gender perspective as urged by The Feminists for a Binding Treaty - a collective of over 15 organisations - appears to have been disregarded. ${ }^{162}$ Notwithstanding this deficit, the draft treaty does represent an important first step towards advancing the legal accountability of multinational businesses including those in the ICT sector. Moreover, as a project in development, there will be opportunities for feminist activists to lobby for the incorporation of stronger provisions in the final text. The ability to secure a more progressive agenda is well within reach; after all, feminist activism has become adept at building effective global coalitions with other interest groups - and on occasion with like-minded States - and to identify strategic moments and openings to secure transformative change. Meanwhile, the door remains open for the possibility of a treaty that will hold businesses to account in international law.

For feminist international lawyers, the challenge is to discover, within the fabric of the law, opportunities for furthering women's human rights and gender equality. ${ }^{163}$ The CEDAW Committee's ability to uncover a positive obligation on States to prevent violence against women within the text of a treaty that, on its face, was silent, demonstrates the potential for such an approach. In the 40 years since the adoption of CEDAW, the Committee has achieved much to advance women's rights and gender equality by adopting a progressive reading of the treaty text, grounded in and informed by the lived and differentiated experiences of women who confront multiple and often intersecting discriminations in their daily lives.

In thinking about how digital technologies have transformed the world, I nevertheless find myself struck by the fact that, far from disrupting traditional distributions of power, ICTs have augmented, enhanced and strengthened the power base of global elites and, in that process, have accentuated gender inequalities in different shapes and patterns. In attempting to understand what is unfolding, I have chosen to seek out and be attentive to the different formations of patriarchal silences if only to recognise how patriarchy operates to normalise gendered hierarchies and to make inequalities seemingly inevitable. Against this backdrop, law has a powerful role to play. After all, human rights are not necessarily or inextricably wedded to any particular political or economic philosophy or tradition. It is the prevailing political and economic ideology, operating in tandem with patriarchy, that produces different understandings of rights, hierarchies of rights, and even the silencing of certain rights. The same can be said of digital technologies. As Wajcman posits, 'all technologies embody and advance political interests and agendas and they are the product of social structure, culture, values, and politics as much as the result of objective scientific discovery'. ${ }^{164}$

As for the future, I remain optimistic. The number of women who are working in the field of digital technologies has grown and is growing. And this is important because it is only when women are at least equal participants and partners in this field that we might begin to see a greater diversity and plurality of views not

162. Felogene Anumo and Layla Hughes, 'The Feminists for a Binding Treaty' (24 January 2019) <www.cidse.org/gender-equality-blog/the-feminists-for-a-binding-treaty.html > accessed 11 July 2019.

163. Of course, the very existence of a legally binding treaty has given women a voice in international law and, at a minimum, has required States to listen.

164. Judy Wajcman, 'ICTs and Inequality: Net Gains for Women?' in Chrisanthi Avgerou, Robin Mansell, Danny Quah et al (eds), The Oxford Handbook of Information and Communication Technologies (OUP, New York 2009). 
only in the design, development and content but also in the purpose of digital technologies. ${ }^{165}$ As with law, technologies can be designed to advance equality, inclusivity, redistributive values, environmental sustainability and a positive peace. The challenges are huge. But alternative histories can be written.

165. '[P]utting women in, allowing them a few odd seats in the previously segregated clubs is not enough. What is needed is for newcomers to be able to be entitled to redefine the rules of the game so as to make a difference and make that difference felt concretely': Rosi Braidotti, Nomadic Subjects: Embodiment and Sexual Difference in Contemporary Feminist Theory (Columbia University Press, New York 1994) 241-242. 